\title{
Coordination Complexes of Niobium and Tantalum Pentahalides with a Bulky NHC Ligand
}

\author{
Marco Bortoluzzi, ${ }^{a}$ Eleonora Ferretti, ${ }^{b, \xi}$ Fabio Marchetti, ${ }^{, b}$ Guido Pampaloni, ${ }^{b}$ and Stefano Zacchini ${ }^{c}$ \\ ${ }^{a}$ Ca' Foscari University of Venezia, Dipartimento di Scienze Molecolari e Nanosistemi Dorsoduro 2137, I-30123 Venezia, Italy. \\ ${ }^{b}$ University of Pisa, Dipartimento di Chimica e Chimica Industriale, Via Moruzzi 13, I-56124 Pisa, Italy. Tel: +39 050 \\ 2219245.E-mail: fabio.marchetti1974@unipi.it.Webpage: http://www.dcci.unipi.it/fabio-marchetti.html. \\ ${ }^{c}$ University of Bologna, Dipartimento di Chimica Industriale "Toso Montanari", Viale Risorgimento 4, I-40136 Bologna, Italy. \\ § Present address: Institut für Anorganische Chemie, Georg-August-Universität Göttingen, Tammannstrasse 4, D-37077 \\ Göttingen, Germany.
}

This submission was created using the RSC Article Template (DO NOT DELETE THIS TEXT)
(LINE INCLUDED FOR SPACING ONLY - DO NOT DELETE THIS TEXT)

The 1:1 molar reactions of niobium and tantalum pentahalides with the monodentate NHC ligand 1,3-bis(2,6-diisopropylphenyl)imidazol-2-ylidene (IPr), in toluene (or benzene) at $c a .80^{\circ} \mathrm{C}$, afforded the complexes $\mathrm{NbX}_{5}(\mathrm{Ipr})(\mathrm{X}=\mathrm{F}, \mathbf{2} ; \mathrm{Br}, \mathbf{3})$ and $\mathrm{TaX}(\mathrm{Ipr})(\mathrm{X}=\mathrm{F}, \mathbf{4} ; \mathrm{Cl}, \mathbf{5} ; \mathrm{Br}, \mathbf{6})$, in generally good yields. Complexes 2-6 represent uncommon cases of stable NHC adducts of metal halides with the metal in oxidation state higher than +4 , and also rare examples of $\mathrm{Nb}-\mathrm{NHC}$ and Ta-NHC bonding systems. In particular, the X-ray molecular structure determined for 6 provides the unprecedented crystallographic characterization of a tantalum compound with a monodentate NHC ligand. DFT results indicate that the metalcarbon bond in 2-6 is a purely $\sigma$ one. According to NMR studies $\left({ }^{1} \mathrm{H},{ }^{13} \mathrm{C},{ }^{93} \mathrm{Nb}\right)$, the formation of $\mathbf{3}, \mathbf{5}, \mathbf{6}$, as well as the previously communicated $\mathrm{NbCl}_{5}(\mathrm{Ipr}), 1$, proceeded with the intermediacy of $\left[\mathrm{MX}_{6}\right]^{-}$salts, presumably due to steric reasons. On the other hand, the intermediate formation of $\mathrm{MF}_{6}{ }^{-}$along the pathways to $\mathbf{2}$ and $\mathbf{4}$ was not observed, according to ${ }^{19} \mathrm{~F}$ (and ${ }^{93} \mathrm{Nb}$ in the case of 2) NMR. DFT calculations were carried out in order to shed light on structural and mechanistic aspects, and allowed to trace possible reaction routes.

\section{Introduction}

$N$-Heterocyclic carbenes (NHC) have marked a revolutionary turning point in coordination chemistry: NHC ligands, whose electronic and steric properties can be finely tuned by the introduction of suitable substituents, usually confer unique properties to the resulting metal complexes. ${ }^{1}$ This point has triggered their pervasive use with reference to the large majority of the metal elements across the periodic table. ${ }^{1,2}$ However, the chemistry of NHCs has predominantly focused on low to medium valent transition metals, instead the isolation of derivatives of oxophilic, high valent metals may be a harder task..$^{2 a, 3}$ Especially the structurally characterized NHC adducts of elements in oxidation state above +4 are rather rare, and include $\mathrm{WO}_{2} \mathrm{Cl}_{2}(\mathrm{NHC})$ and $\mathrm{VOCl}_{3}(\mathrm{NHC})$ complexes. $^{3 \mathrm{a}, 4}$ This is a consequence of the moisture sensitivity generally suffered by the reaction systems, that may be progressively decreased on replacing the halide ligands with oxido groups. ${ }^{3 a}$

It should be noted also that niobium and tantalum are surprising exceptions in the crowded scenario of the NHC chemistry; ${ }^{5}$ as a matter of fact, only few NHC complexes based on $\mathrm{Nb}$ or Ta have been prepared and/or structurally characterized up to now, ${ }^{5,6}$ and in most cases the NHC moiety is a component of a multidentate ligand rendering the coordination more robust. ${ }^{6-\mathrm{c}}$ Nearly 20 years ago Kempe stated that "niobium and tantalum compounds live in the shadow of metal complexes of group 4", 7 as a reflection of the greater performance of the latter in alkene polymerization reactions compared to the former. ${ }^{8}$ The last decade has witnessed a significant progress in the chemistry of niobium and tantalum halides, encouraged by cost effectiveness, low toxicity associated with the metal element and unusual reactivity patterns. ${ }^{9}$ Recently, we have reported the synthesis and the structural characterization of $\mathrm{NbCl}_{5}(\mathrm{Ipr}), \mathbf{1}, \mathrm{Ipr}=1,3$-bis $(2,6-$ diisopropylphenyl)imidazol-2-ylidene, providing the first example of a niobium complex with a monodentate NHC ligand..$^{5}$ This complex exhibits an abnormally long niobium-carbon bond, consisting in a substantially pure $\sigma$ interaction. In contrast, it should be remarked that the metal-carbon bond in a series of NHC complexes with $\mathrm{d}^{0}$ high valent transition metal chlorides was speculated to hold some $\pi$ character, resulting from back donation of electron density from chloride lone pairs to some vacant molecular orbital situated on the carbene carbon. ${ }^{3 a-b-d, 4 b, 10}$

Herein, we extend the series of niobium and tantalum pentahalides (from fluorides to bromides) adducts with a monodentate $\mathrm{NHC}$ ligand (Ipr), including the unprecedented crystallographic characterization of a high valent bromide - NHC complex. The synthesis, the reaction mechanism, and the structural features of the products will be discussed, with the assistance of extensive DFT calculations. The new complexes may find potential application in $\mathrm{Nb}$ and Ta based organic synthesis.

\section{Results and Discussion}

The reactions of niobium and tantalum pentahalides ${ }^{11,12}$ with the bulky NHC ligand 1,3-bis(2,6-diisopropyl-phenyl)imidazol-2ylidene, Ipr, were conducted in toluene at $80{ }^{\circ} \mathrm{C}$ by using $\mathrm{NHC} /$ metal $=1$ molar ratio. The mononuclear complexes $\mathrm{MX}_{5}(\mathrm{Ipr})$, 2-6, were isolated in 47-64\% yield after work up (Scheme 1).

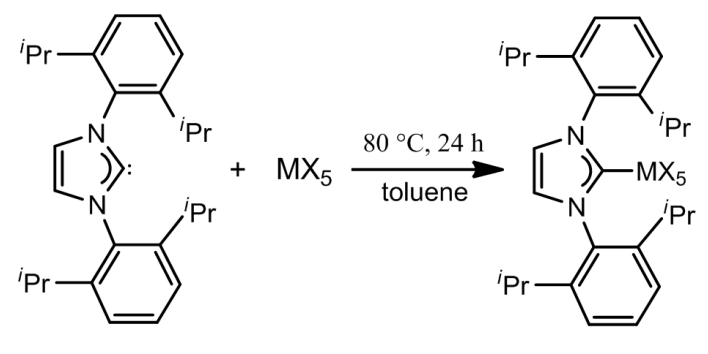

Ipr 


\begin{tabular}{lll}
$\mathrm{Nb}$ & $\mathrm{F}$ & $\mathbf{2}$ \\
$\mathrm{Nb}$ & $\mathrm{Br}$ & $\mathbf{3}$ \\
$\mathrm{Ta}$ & $\mathrm{F}$ & $\mathbf{4}$ \\
$\mathrm{Ta}$ & $\mathrm{Cl}$ & $\mathbf{5}$ \\
$\mathrm{Ta}$ & $\mathrm{Br}$ & $\mathbf{6}$ \\
\hline
\end{tabular}

Scheme 1. Synthesis of NHC complexes of niobium and tantalum pentahalides.

Once isolated in the solid state, 2-6 are almost not soluble in the reaction solvent. They rapidly convert into degradation products in more polar solvents, and into the relevant imidazolium salts in the presence of traces of water. ${ }^{6 \mathrm{~d}}$ Compounds 2-6 were stored under nitrogen atmosphere and characterized by elemental analysis and IR spectroscopy (in the solid state). The main IR feature is given by the disappearance of the strong band at $1670 \mathrm{~cm}^{-1}$, as observed in non coordinated Ipr. ${ }^{13}$ The NMR characterization of 2-6 was performed on solutions obtained by allowing $\mathrm{MX}_{5}$ to react with Ipr directly in the deuterated solvent (toluene or benzene), in conditions analogous to those used for the isolation of the solid materials. The ${ }^{1} \mathrm{H}$ NMR and most of the ${ }^{13} \mathrm{C}$ resonances attributed to 2-6 are slightly shifted with reference to the corresponding values characteristic of Ipr. ${ }^{14}$ Instead the resonances related to $\mathrm{C} 2$ and $\mathrm{C} 3$ and to the carbenic $\mathrm{C} 1$ (see Chart 1), when it has been possible to detect it (by 2D experiments), undergo major shifts. In particular, the $\mathrm{C} 1$ nucleus resonates at $c a .190 \mathrm{ppm}$ in $\mathbf{5}$ and $\mathbf{6}$ while it falls at $220.6 \mathrm{ppm}$ in non coordinated $\operatorname{Ipr}\left(\mathrm{C}_{6} \mathrm{D}_{6}\right.$ solution $) .{ }^{14}$ The ${ }^{19} \mathrm{~F}$ NMR spectra of $\mathbf{2}$ and $\mathbf{4}$ display a single fluorine peak, at 129.7 and $81.9 \mathrm{ppm}$ respectively, indicating rapid exchange of all five $\mathrm{F}$ atoms at room temperature. The same situation is frequently observed with mononuclear $\mathrm{MF}_{5} \mathrm{~L}$ complexes $(\mathrm{M}=\mathrm{Nb}$ or $\mathrm{Ta}, \mathrm{L}=$ group 15 or group 16 donor ligand), ${ }^{9 f, 15}$ and low temperature ${ }^{19} \mathrm{~F}$ NMR experiments often permit to discriminate between the axial fluorine and the four equatorial fluorines within the octahedral $\mathrm{MF}_{5} \mathrm{~L}$ structure. ${ }^{15}$ It should be remarked that the ${ }^{19} \mathrm{~F}$ NMR spectra of ionic complexes containing the $\left[\mathrm{MF}_{6}\right]^{-}$anion usually show a typical resonance at room temperature $(\mathrm{M}=\mathrm{Nb}$, decet centred at ca. $103 \mathrm{ppm} ; \mathrm{M}=\mathrm{Ta}$, sharp singlet at $c a .39 \mathrm{ppm}){ }^{9 \mathrm{f}, 15,16}$ The ${ }^{19} \mathrm{~F}$ NMR spectrum of 2 (in $\mathrm{D}^{8}$-toluene) did not significantly change on cooling to $-60{ }^{\circ} \mathrm{C}$. Unfortunately, analyses at lower temperature were inhibited by low solubility, thus preventing us to see the expected splitting of the ${ }^{19} \mathrm{~F}$ pattern on the NMR timescale.

The ${ }^{93} \mathrm{Nb}$ NMR spectra recorded for $\mathbf{2}, \mathbf{3}$ and the previously reported complex 1 show a unique, broad resonance $(\mathbf{1},-318 \mathrm{ppm}$; 2, $-1447 \mathrm{ppm} ; \mathbf{3},-65 \mathrm{ppm}){ }^{15 \mathrm{~b}, \mathrm{~d}, 17}$ The NMR spectra of $\mathbf{6}$ contain two sets of resonances, due to the presence of a co-product, that will be discussed in the following.

After several attempts, crystals suitable for X-ray analysis could be collected for 6 from a toluene/pentane mixture stored at $-30{ }^{\circ} \mathrm{C}$. The molecular structure ascertained for $\mathbf{6}$ (Figure 1, Table 1) provides: 1) the unprecedented crystallographic characterization of a Ta-monodentate NHC complex; 2) a very rare example of a high valent bromide-NHC complex; 3) a rare example of a $\mathrm{TaBr}_{5}$ coordination compound. ${ }^{9 \mathrm{f}, 18}$

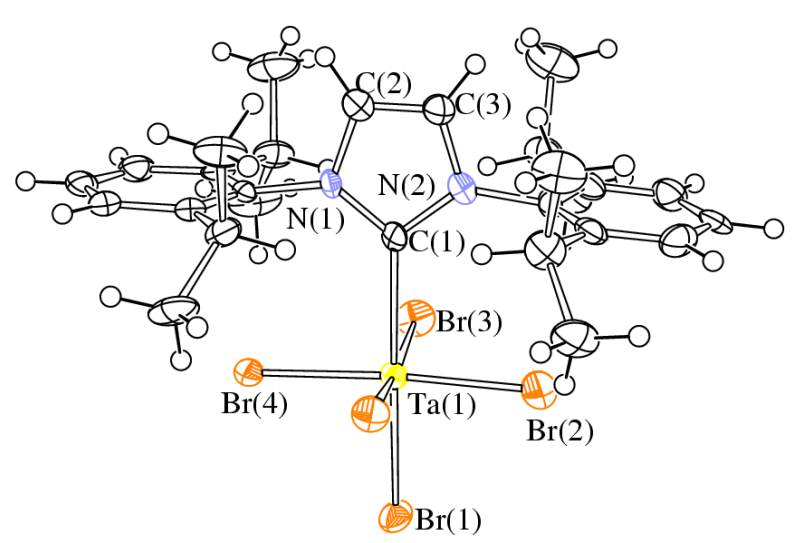

Figure 1. Molecular structure of $\mathrm{TaBr}_{5}(\mathrm{Ipr}), \mathbf{6}$, with key atoms labeled. Displacement ellipsoids are at the $50 \%$ probability level.

Table 1.Selected bond distances $(\AA)$ and angles $\left(^{\circ}\right)$ for 6 .

\begin{tabular}{llll}
$\mathrm{Ta}(1)-\mathrm{C}(1)$ & $2.383(10)$ & $\mathrm{Ta}(1)-\mathrm{Br}(1)$ & $2.5193(13)$ \\
$\mathrm{Ta}(1)-\mathrm{Br}(2)$ & $2.4281(15)$ & $\mathrm{Ta}(1)-\mathrm{Br}(3)$ & $2.4852(13)$ \\
$\mathrm{Ta}(1)-\mathrm{Br}(4)$ & $2.4529(12)$ & $\mathrm{Ta}(1)-\mathrm{Br}(5)$ & $2.4788(12)$ \\
$\mathrm{C}(1)-\mathrm{N}(1)$ & $1.354(13)$ & $\mathrm{C}(1)-\mathrm{N}(2)$ & $1.392(12)$ \\
$\mathrm{N}(1)-\mathrm{C}(2)$ & $1.392(13)$ & $\mathrm{N}(2)-\mathrm{C}(3)$ & $1.352(14)$ \\
$\mathrm{C}(2)-\mathrm{C}(3)$ & $1.308(16)$ & & \\
& & & \\
$\mathrm{Br}(1)-\mathrm{Ta}(1)-\mathrm{C}(1)$ & $177.5(2)$ & $\mathrm{Br}(2)-\mathrm{Ta}(1)-\mathrm{Br}(4)$ & $175.77(4)$ \\
$\mathrm{Br}(3)-\mathrm{Ta}(1)-\mathrm{Br}(5)$ & $170.26(4)$ & $\mathrm{Ta}(1)-\mathrm{C}(1)-\mathrm{N}(1)$ & $129.8(7)$ \\
$\mathrm{Ta}(1)-\mathrm{C}(1)-\mathrm{N}(2)$ & $127.4(7)$ & $\mathrm{N}(1)-\mathrm{C}(1)-\mathrm{N}(2)$ & $102.8(8)$ \\
$\mathrm{C}(1)-\mathrm{N}(1)-\mathrm{C}(2)$ & $111.0(8)$ & $\mathrm{N}(1)-\mathrm{C}(2)-\mathrm{C}(3)$ & $129.1(7)$ \\
$\mathrm{C}(2)-\mathrm{C}(3)-\mathrm{N}(2)$ & $108.8(10)$ & $\mathrm{C}(3)-\mathrm{N}(2)-\mathrm{C}(1)$ & $110.6(9)$ \\
\hline
\end{tabular}

The $\mathrm{Ta}(1)$ centre in $\mathbf{6}$ displays an octahedral coordination, being bonded to five bromides and one carbene ligand. Differently from $\mathrm{NbCl}_{5}(\mathrm{IPr}){ }^{5} \mathrm{Ta}(1)$ lays almost on the same plane of the four equatorial bromides (displacement $=0.064 \AA$ ). The bonding parameters within the Ipr ligand are in good agreement with those previously found in other complexes, ${ }^{3 a, 10}$ and the $\mathrm{Ta}(1)-\mathrm{C}(2)$ contact $[2.383(10) \AA]$ resembles what found in $\mathrm{Ta}(\mathrm{V})$ complexes with a pincer NHC ligand. ${ }^{6 \mathrm{~b}}$ The carbenic $\mathrm{C}(1)$ atom displays $\mathrm{C} \cdots \mathrm{Br}$ contacts with the four equatorial Br-ligands [3.265-3.476 $\AA]$, these distances being significantly below the sum of the van der Waals radii [3.85 $\AA$ ]. In accordance with DFT calculations and in analogy with previous findings on $\mathrm{NbCl}_{5}(\mathrm{IPr}){ }^{5}$ such feature is probably ascribable to some intramolecular electrostatic interaction, and should not be interpreted as $\pi$ bonding between the Br-lone pairs and the carbene unit. The occurrence of such $\pi$ interaction was previously proposed for other high valent metal halide complexes with bulky NHC ligands (see Introduction).

The structures of complexes 2-6 were calculated by DFT. Views of the structures, together with the calculated structure of 1,5 are shown in Figure 2, and relevant bonding parameters are given in Table 2. It is remarkable that the calculated metal-carbene bond distance slightly decreases on decreasing the size of the halide ligands, suggesting that these play a steric role contributing to the elongation of the metal- $\mathrm{C}$ bond. Nevertheless, such distances remain relatively long in the fluoride complexes, and especially $\mathrm{Nb}-\mathrm{C}$ in $\mathbf{2}$ is significantly longer compared to typical $\mathrm{Nb}(\mathrm{V})-\mathrm{C}$ bond lengths. ${ }^{19}$ Therefore, the coordination of Ipr in 1-6 should be viewed as a relatively weak one. 

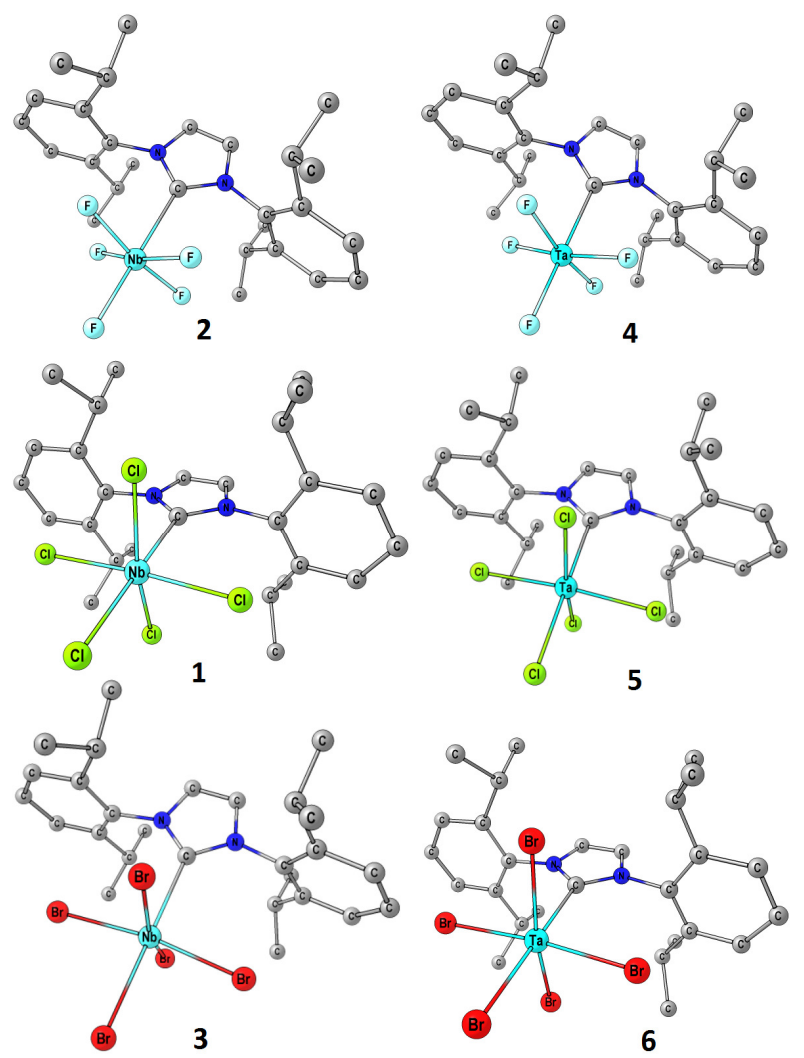

Figure 2. DFT-optimized structures of $\mathrm{MX}_{5}(\mathrm{Ipr})$ complexes $(\mathrm{M}=\mathrm{Nb}$, Ta; $\mathrm{X}=\mathrm{F}, \mathrm{Cl}, \mathrm{Br}) . \mathrm{C}-\mathrm{PCM} / \omega \mathrm{B} 97 \mathrm{X} / \mathrm{BS} 1$ calculations, dichloromethane as implicit solvent. Hydrogen atoms have been omitted for clarity.

Table 2. Selected computed bond lengths $(\AA)$ and angles $\left(^{\circ}\right)$ for 1-6; C$\mathrm{PCM} / \omega \mathrm{B} 97 \mathrm{X} / \mathrm{BS} 1$ calculations, dichloromethane as implicit solvent.

\begin{tabular}{|c|c|c|c|}
\hline$(X$ cis to $C)$ & $\begin{array}{c}\mathbf{M}-\mathbf{C} \\
(X \text { trans to } C)\end{array}$ & $\begin{array}{l}\mathbf{M}-\mathbf{X} \\
(X \text { trans to } C) \\
(X \text { cis to } C)\end{array}$ & $\mathbf{M}-\mathbf{X}$ \\
\hline $2(\mathrm{M}=\mathrm{Nb}, \mathrm{X}=\mathrm{F})$ & 2.348 & 1.878 & $\begin{array}{l}1.883 \\
1.883 \\
1.883 \\
1.883\end{array}$ \\
\hline $4(\mathrm{M}=\mathrm{Ta}, \mathrm{X}=\mathrm{F})$ & 2.355 & 1.898 & $\begin{array}{l}1.902 \\
1.902 \\
1.903 \\
1.903\end{array}$ \\
\hline $\mathbf{1}(\mathrm{M}=\mathrm{Nb}, \mathrm{X}=\mathrm{Cl})$ & 2.407 & 2.359 & $\begin{array}{l}2.328 \\
2.328 \\
2.340 \\
2.341\end{array}$ \\
\hline $5(\mathrm{M}=\mathrm{Ta}, \mathrm{X}=\mathrm{Cl})$ & 2.416 & 2.363 & $\begin{array}{l}2.342 \\
2.343 \\
2.353 \\
2.353\end{array}$ \\
\hline $3(\mathrm{M}=\mathrm{Nb}, \mathrm{X}=\mathrm{Br})$ & 2.435 & 2.546 & $\begin{array}{l}2.484 \\
2.484 \\
2.495 \\
2.495\end{array}$ \\
\hline $6(\mathrm{M}=\mathrm{Ta}, \mathrm{X}=\mathrm{Br})$ & 2.449 & 2.538 & $\begin{array}{l}2.499 \\
2.500 \\
2.508 \\
2.508\end{array}$ \\
\hline
\end{tabular}

Table 3 reports the occupied molecular orbitals most probably involved in the covalent interaction between the NHC ligand and the $\mathrm{MX}_{5}$ fragment, and the calculated enthalpy values referred to the dissociation reaction $\mathrm{MX}_{5}(\mathrm{Ipr}) \rightarrow \mathrm{MX}_{5}+$ Ipr. Selected molecular orbitals are represented in Figure 3. Little structural changes are predicted on replacing niobium with tantalum, conversely the $\mathrm{M}-\mathrm{C}$ bond does appear strongly influenced by the nature of the ancillary halide ligands. In all of the cases, the $\mathrm{M}-\mathrm{C}$ bond is $\sigma$-type, with the metal centre participating prevalently with $s$ and $d$ orbitals. No meaningful M-NHC $\pi$-interaction was found (see above discussion of the X-ray structure of 6). On increasing the electronegativity of the halogen, the energy of the MOs lowers with respect to the HOMO and the M-C overlap steps down, while electrostatic interactions between $\mathrm{M}$ and Ipr progressively reinforce the covalent $\mathrm{M}-\mathrm{C}$ bond. As a matter of fact, 1-6 show several highenergy occupied MOs, thus suggesting an accumulation of electron density in the region of the formal lone pair belonging to the carbenic carbon, without significant orbital participation from the metal. The electrostatic contribution would explain why the calculated dissociation enthalpy of the M-C bond in $\mathbf{2}$ and $\mathbf{4}$ is comparable with that of the other complexes along the series 1-6, despite the expected lower degree of covalency in the former.

Table 3. Occupied MOs most involved in the M-Ipr covalent interactions (orbital energies in $\mathrm{eV}$ ) and $\mathrm{M}-\mathrm{C}$ dissociation enthalpy values ( $\mathrm{kcal} \mathrm{mol}^{-1}$. $\mathrm{C}-\mathrm{PCM} / \omega \mathrm{B} 97 \mathrm{X} / \mathrm{BS} 2$ calculations).

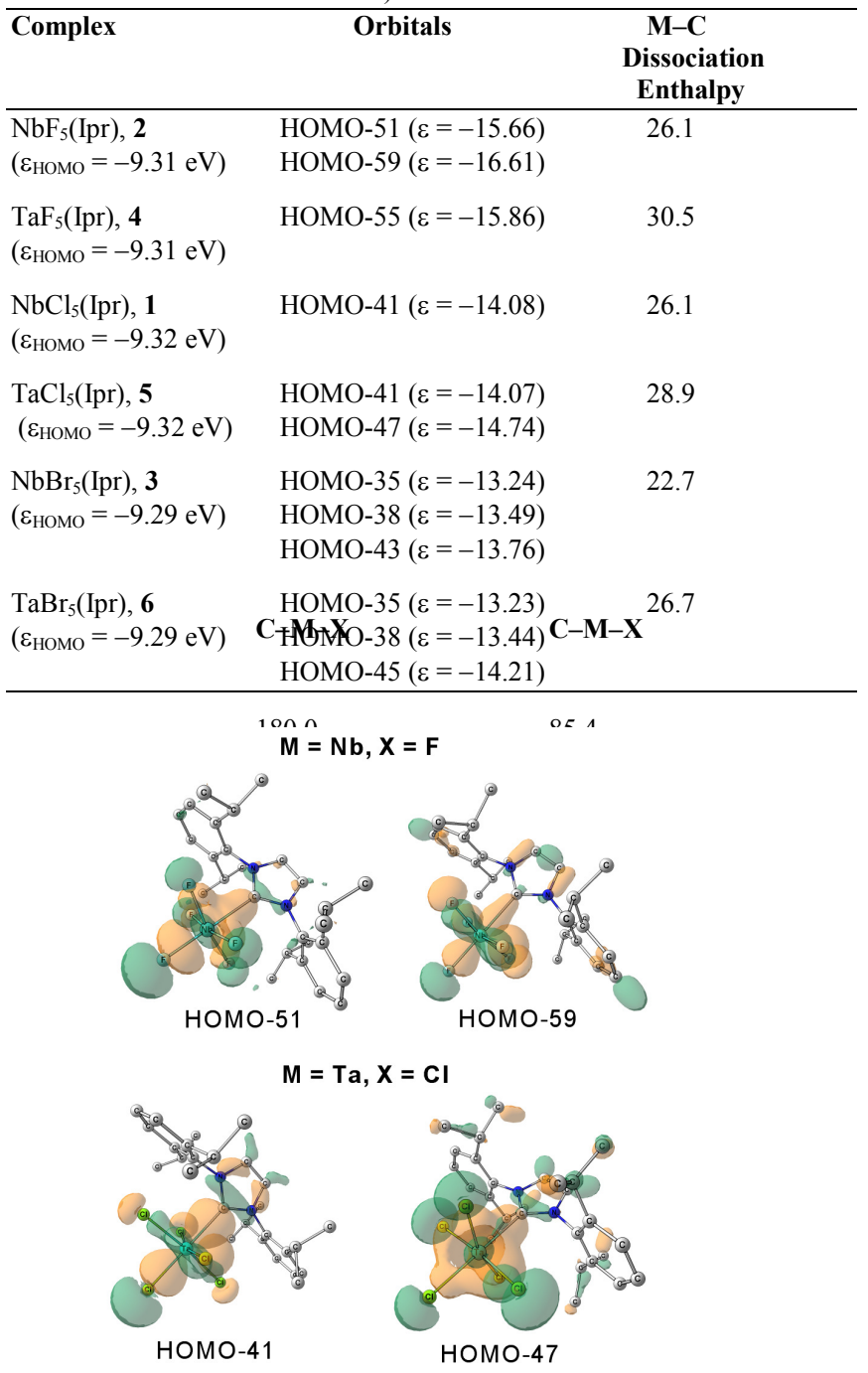

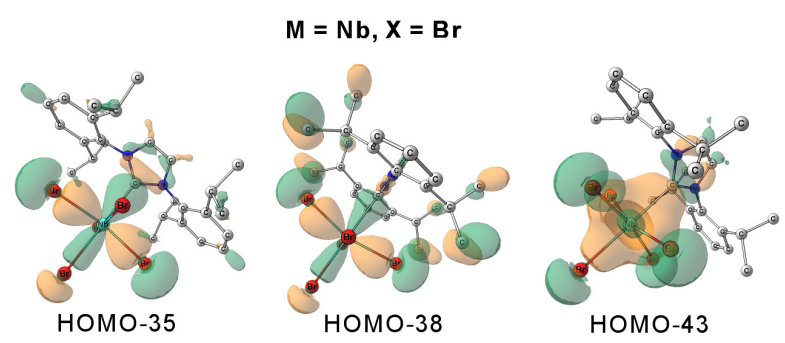


Figure 3. Selected occupied MOs of some $\mathrm{MX}_{5}(\mathrm{Ipr})$ complexes. Surface isovalue $=0.03$ a.u.

By means of NMR studies, we noticed that the reactions of $\mathrm{MX}_{5}$ $(\mathrm{X}=\mathrm{Cl}, \mathrm{Br})$ with $\mathrm{Ipr}$ at room temperature proceeded with the formation of an intermediate product, converting into 1,3,5,6 upon prolonged reaction times. In order to complete the conversion, the $\mathrm{TaCl}_{5} / \mathrm{Ipr}$ system required thermal treatment. In general, high temperature conditions were used for optimizing the synthesis of 16 (Scheme 1), although these conditions were not effective to complete the conversion in the case of $\mathrm{TaBr}_{5} / \mathrm{Ipr}$ (see above). More in detail, ${ }^{93} \mathrm{Nb}$ NMR spectroscopy unambiguously revealed the presence of $\left[\mathrm{NbCl}_{6}\right]^{-}(\delta=8 \mathrm{ppm})^{9 \mathrm{9}, 16 \mathrm{a}-\mathrm{b}, 17,20}$ and $\left[\mathrm{NbBr}_{6}\right]^{-}(\delta=735$ ppm) ${ }^{21}$ anions in the solutions obtained at room temperature from $\mathrm{NbCl}_{5} / \mathrm{Ipr}$ and $\mathrm{NbBr}_{5} / \mathrm{Ipr}$, respectively, after 30 minutes. In the absence of ${ }^{93} \mathrm{Nb}$ data, the formation of an intermediate species from $\mathrm{TaX}_{5} /$ Ipr could be detected by ${ }^{1} \mathrm{H}$ NMR: the resonance values due to the methyl groups and $\mathrm{C} 2-\mathrm{H}$ (see Experimental, Chart 1) undergo significant shift, on going from the respective intermediate to 5-6 (e.g. for $\mathrm{TaCl}_{5} / \mathrm{Ipr}: \Delta \delta_{\mathrm{C} 2-\mathrm{H}}=0.37 \mathrm{ppm}$ ). Interestingly, ${ }^{1} \mathrm{H}$ and ${ }^{19} \mathrm{~F}$ NMR spectroscopy ruled out the formation of $\left[\mathrm{TaF}_{6}\right]^{-}$from $\mathrm{TaF}_{5} / \mathrm{Ipr}$, whereas $\left[\mathrm{NbF}_{6}\right]^{-}$was recognized in traces within the $\mathrm{NbF}_{5} / \mathrm{Ipr}$ system at the beginning of the reaction.

In order to shed light on the mechanisms of the reactions leading to 1-6, we carried out DFT studies (C-PCM/ $/ \mathrm{BB} 97 \mathrm{X} / \mathrm{BS} 2)$. First, it should be clarified that the $\Delta \mathrm{G}$ variation for $\mathrm{M}_{2} \mathrm{X}_{10}+2 \mathrm{Ipr} \rightarrow$ $2 \mathrm{MX}_{5}(\mathrm{Ipr})(\mathrm{X}=\mathrm{Cl}$ or $\mathrm{Br})$ is quite favourable in the distinct cases (Scheme 2).

\begin{tabular}{llcc}
$\mathbf{M}_{\mathbf{2}} \mathbf{X}_{\mathbf{1 0}}+\mathbf{+} \mathbf{2} \mathbf{I p r} \rightarrow \mathbf{2} \mathbf{M} \mathbf{X}_{\mathbf{5}}$ (Ipr) & \\
& $\mathrm{M}$ & $\mathrm{X}$ & $\Delta \mathrm{G}\left(\mathrm{kcal} \mathrm{mol}^{-1}\right)$ \\
\hline $\mathbf{1}$ & $\mathrm{Nb}$ & $\mathrm{Cl}$ & $-45.7^{22}$ \\
$\mathbf{3}$ & $\mathrm{Nb}$ & $\mathrm{Br}$ & -34.7 \\
$\mathbf{5}$ & $\mathrm{Ta}$ & $\mathrm{Cl}$ & -42.3 \\
$\mathbf{6}$ & $\mathrm{Ta}$ & $\mathrm{Br}$ & -40.3 \\
\hline
\end{tabular}

Scheme 2. Calculated $\Delta \mathrm{G}$ values (at $298 \mathrm{~K}$ ) for the formation of $\mathrm{MCl}_{5}$ and $\mathrm{MBr}_{5}$ adducts.

The addition of a neutral ligand (L) to $\mathrm{MX}_{5}(\mathrm{X}=\mathrm{Cl}, \mathrm{Br})$ typically results in either symmetric or asymmetric cleavage of the dimetallic structure, ${ }^{11}$ affording $\mathrm{MX}_{5}(\mathrm{~L})$ and $\left[\mathrm{MX}_{4}(\mathrm{~L})_{2}\right]\left[\mathrm{MX}_{6}\right]$ complexes, respectively. ${ }^{9 f, 15,16 a, 18}$ In view of the encumbrance of Ipr, the "asymmetric route" accompanied by the binding of only one NHC molecule might be kinetically convenient in principle. Therefore, we evaluated the possible formation of ionic compounds of formula $\left[\mathrm{MX}_{4}(\mathrm{Ipr})\right]\left[\mathrm{MX}_{6}\right](\mathrm{X}=\mathrm{Cl}, \mathrm{Br})$, and this resulted substantially viable on the basis of $\Delta \mathrm{G}$ data (Scheme 3 ).

$\mathrm{M}_{2} \mathrm{X}_{10}+\mathrm{Ipr} \rightarrow\left[\mathrm{MX}_{4}(\mathrm{Ipr})\right]\left[\mathrm{MX}_{6}\right]$

\begin{tabular}{lll}
$\mathrm{M}$ & $\mathrm{X}$ & $\Delta \mathrm{G}\left(\mathrm{kcal} \mathrm{mol}^{-1}\right)$ \\
\hline $\mathrm{Nb}$ & $\mathrm{Cl}$ & $-26.4^{23}$ \\
$\mathrm{Nb}$ & $\mathrm{Br}$ & -28.2 \\
$\mathrm{Ta}$ & $\mathrm{Cl}$ & -24.3 \\
$\mathrm{Ta}$ & $\mathrm{Br}$ & -30.8 \\
\hline
\end{tabular}

Scheme 3. Calculated $\Delta \mathrm{G}$ values (at $298 \mathrm{~K}$ ) for the supposed formation of $\left[\mathrm{MX}_{4}(\mathrm{Ipr})\right]\left[\mathrm{MX}_{6}\right](\mathrm{X}=\mathrm{Cl}, \mathrm{Br})$ intermediates.

A view of the cationic part of $\left[\mathrm{NbCl}_{4}(\mathrm{Ipr})\right]\left[\mathrm{NbCl}_{6}\right]$ is reproduced in Figure 4. The full data of the calculated structures of $\left[\mathrm{MX}_{4}(\mathrm{Ipr})\right]\left[\mathrm{MX}_{6}\right](\mathrm{X}=\mathrm{Cl}, \mathrm{Br})$ are supplied as Supporting Information (Figures S1-S4 and Tables S1-S4).

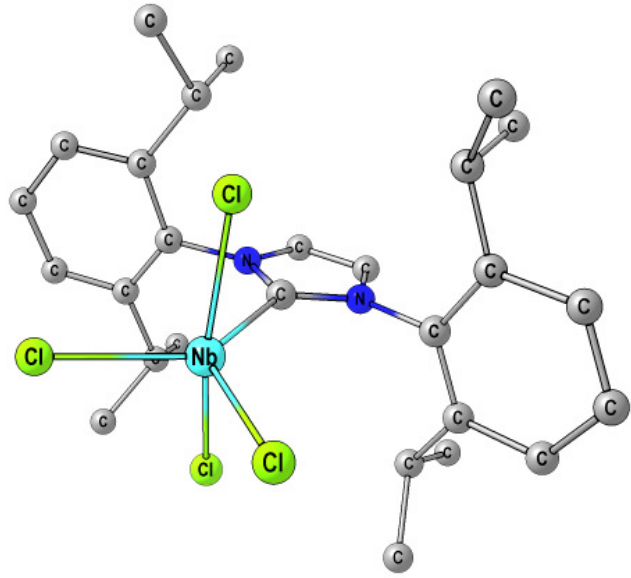

Figure 4. View of the calculated structure of the cation $\left[\mathrm{NbCl}_{4}(\operatorname{Ipr})\right]^{+}$in

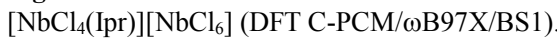

The possible, initial formation of ionic complexes by addition of Ipr to the metal pentachlorides or pentabromides is consistent with the NMR detection at room temperature of the respective $\left[\mathrm{MX}_{6}\right]^{-}$ anions (see above). On theoretical grounds, the addition of further Ipr to the initially generated $\left[\mathrm{MX}_{4}(\mathrm{Ipr})\right]\left[\mathrm{MX}_{6}\right]$ might lead to the bis-carbene $\left[\mathrm{MX}_{4}(\mathrm{Ipr})_{2}\right]\left[\mathrm{MX}_{6}\right]$, for which the calculations indicated the trans form as the stable one (Figures S5-S8, Tables S5-S8). The Gibbs energy variation for such addition ranges in between -7.2 and $-1.6 \mathrm{kcal} \mathrm{mol}^{-1}$, and the $\Delta \mathrm{H}$ associated to the formation of the new $\mathrm{M}-\mathrm{C}$ bond is comparable to the values calculated for the direct combination of Ipr with $\mathrm{MX}_{5}$ ( $c a .-25 \mathrm{kcal} \mathrm{mol}^{-1}$, see Table 3 for comparison). However, since the hypothetical, successive rearrangement of $\left[\mathrm{MX}_{4}(\mathrm{Ipr})_{2}\right]\left[\mathrm{MX}_{6}\right]$ to $\mathrm{MX}_{5}(\mathrm{Ipr})(\mathrm{X}=\mathrm{Cl}, \mathrm{Br})$ would pass through poorly stable heptacoordinated species, it is likely that the bis-carbene ionic complex does not behave as a key intermediate along the formation of $\mathrm{MX}_{5}(\mathrm{Ipr})$.

On the other hand, the transformation of $\left[\mathrm{MX}_{4}(\mathrm{Ipr})\right]\left[\mathrm{MX}_{6}\right]$ into $\mathrm{MX}_{5}(\mathrm{Ipr})$ and $\mathrm{MX}_{5}$ was calculated to be a moderately exergonic process for $\mathrm{X}=\mathrm{Cl}$ and a slightly endoergonic one for $\mathrm{NbBr}_{5} / \mathrm{Ipr}$, at $298 \mathrm{~K}$ (Scheme 4). The combination of the released mononuclear fragment $\mathrm{MX}_{5}$ with still unreacted Ipr giving $\mathrm{MX}_{5}(\mathrm{Ipr})$ could provide driving force to the formation of $\mathrm{MX}_{5}(\mathrm{Ipr}) \cdot{ }^{24}$ Interestingly, the calculated positive $\Delta \mathrm{G}$ referred to the reaction $\left[\mathrm{TaBr}_{4}(\operatorname{Ipr})\right]\left[\mathrm{TaBr}_{6}\right] \rightarrow \mathrm{TaBr}_{5}(\mathrm{Ipr})$ (Scheme 4) seems to be in alignment with the persistent presence of two products in the reaction system $\mathrm{TaBr}_{5} / \mathrm{Ipr}$, even after prolonged heating (see above).

$\left[\mathbf{M X}_{4}(\mathrm{Ipr})\right]\left[\mathbf{M X}_{6}\right] \rightarrow \mathrm{MX}_{5}(\mathrm{Ipr})+\mathrm{MX}_{5}$

\begin{tabular}{llc}
$\mathrm{M}$ & $\mathrm{X}$ & $\Delta \mathrm{G}\left(\mathrm{kcal} \mathrm{mol}^{-1}\right)$ \\
\hline $\mathrm{Nb}$ & $\mathrm{Cl}$ & $-5.9^{25}$ \\
$\mathrm{Nb}$ & $\mathrm{Br}$ & +0.9 \\
$\mathrm{Ta}$ & $\mathrm{Cl}$ & -4.7 \\
$\mathrm{Ta}$ & $\mathrm{Br}$ & +2.3 \\
\hline
\end{tabular}

Scheme 4. Calculated $\Delta \mathrm{G}$ values (at $298 \mathrm{~K}$ ) for the rearrangement from ionic to neutral NHC adducts of $\mathrm{MX}_{5}(\mathrm{X}=\mathrm{Cl}, \mathrm{Br})$.

The proposed reaction pathway for the reaction between $\mathrm{NbCl}_{5}$ and Ipr is sketched in Scheme 5. 


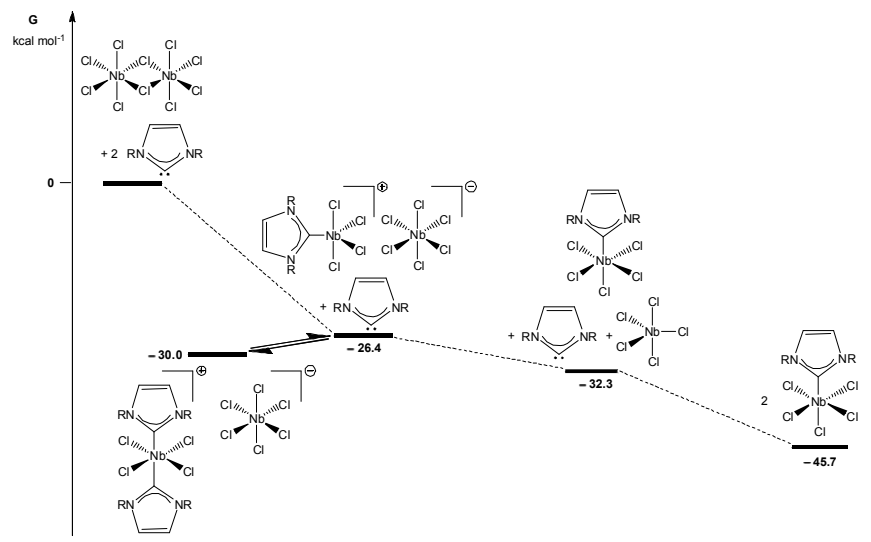

Scheme 5. Proposed reaction pathway for the reaction $\mathrm{Nb}_{2} \mathrm{Cl}_{10}+2 \mathrm{Ipr} \rightarrow$ $2 \mathrm{NbCl}_{5}(\mathrm{Ipr}), \mathrm{R}={ }^{i} \mathrm{Pr}$ ) (1). Calculated $\mathrm{G}$ values refer to $298 \mathrm{~K}$.

DFT calculations pointed out that the asymmetric rupture of the tetranuclear structure of $\mathrm{NbF}_{5}{ }^{11}$ to give $\left[\mathrm{NbF}_{4}(\mathrm{Ipr})\right]\left[\mathrm{NbF}_{6}\right]$ is

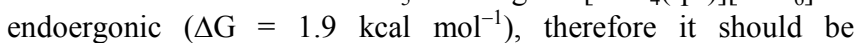
considered a non feasible pathway along the formation of $\mathrm{NbF}_{5}(\mathrm{Ipr}), 2\left[1 / 4 \mathrm{Nb}_{4} \mathrm{~F}_{20}+\mathrm{Ipr} \rightarrow \mathrm{NbF}_{5}(\mathrm{Ipr}), \Delta \mathrm{G}=-31.0 \mathrm{kcal}\right.$ $\mathrm{mol}^{-1}$ ]. This computer outcome agrees with the experimental evidence that $\left[\mathrm{MF}_{6}\right]^{-}$may form only to a negligible degree in the course of the reactions between $\mathrm{MF}_{5}$ and Ipr (see above). It seems plausible that steric factors are less important, in the case of the fluorides respect to the other more hindered metal halides, thus disfavouring the initial, asymmetric rupture of the polynuclear $\mathrm{MF}_{5}$ frame.

A theoretically stable compound, possibly implicated in the pathway leading to 2 , was ascertained by DFT calculations (EDF2/BS3): this is a tetraniobium complex, comprising one heptacoordinated metal centre (Figure S9, Table S9). With the aim of investigating the point, we performed and monitored by NMR the reactions of $\mathrm{MF}_{5}(\mathrm{M}=\mathrm{Nb}$, Ta) with Ipr in 4:1 molar ratio, in deuterated toluene (see NMR studies, part 2). The NMR analyses supported the hypothesis of formation of some intermediate metal species, that, however, could not be unambiguously identified.

We tried to extend the synthesis of $\mathrm{MX}_{5}$ complexes by studying the reactions with bulky $\mathrm{NHC}$ ligands different from Ipr, i.e. 1,3bis(2,6-dimethylphenyl)imidazol-2-ylidene (Ixyl) and 1,3bis(2,4,6-trimethylphenyl)imidazol-2-ylidene (Imes). Unfortunately, the scarce solubility of the resulting mixtures prevented their NMR characterization and, thus, did not allow to identify the products. In order to enhance solubility, we tried to dissolve the mixtures into chlorinated solvents, acetonitrile or acetone. In these conditions, and similarly to what observed for 1-6 (see above), degradation reactions took place prevalently affording imidazolium derivatives. In particular, we could isolate $[\mathrm{IxylH}]\left[\mathrm{TaF}_{6}\right], 7$, as a crystalline material in $25 \%$ yield, from $\mathrm{TaF}_{5} / \mathrm{Ixyl} / \mathrm{CH}_{2} \mathrm{Cl}_{2}$.

The X-ray molecular structure of 7 was determined (Figure 5, Table 4). It consists of an ionic packing of $[\mathrm{IxylH}]^{+}$imidazolium cations and $\left[\mathrm{TaF}_{6}\right]^{-}$anions, with some short inter-molecular contacts (in the range 2.362-2.645 $\AA$ ) between the fluorine atoms of the anions and the $\mathrm{H}$-atoms of the cations (sum of the Van der Waals radii $2.80 \AA$ ). ${ }^{26}$ The structures of both the cation ${ }^{27}$ and the anion ${ }^{28}$ were, previously, independently determined in different salts, showing bonding parameters analogous to those found for 7 .
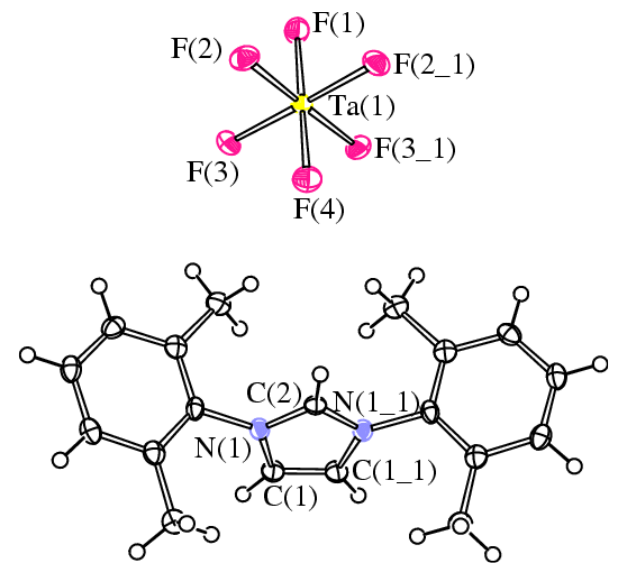

Figure 5. Molecular structure of $\left[\mathrm{IxylH}_{\mathrm{H}}\right]\left[\mathrm{TaF}_{6}\right]$, 7, with key atoms labeled. Displacement ellipsoids are at the $50 \%$ probability level. Symmetry transformation used to generate equivalent atoms: $x,-y+3 / 2, z$.

Table 4. Selected bond lengths $(\AA)$ and angles (deg) for 7 .

\begin{tabular}{|c|c|c|c|}
\hline $\mathrm{Ta}(1)-\mathrm{F}(1)$ & $1.902(3)$ & $\mathrm{Ta}(1)-\mathrm{F}(2)$ & $1.891(2)$ \\
\hline $\mathrm{Ta}(1)-\mathrm{F}(3)$ & $1.896(2)$ & $\mathrm{Ta}(1)-\mathrm{F}(4)$ & $1.895(3)$ \\
\hline $\mathrm{C}(1)-\mathrm{N}(1)$ & $1.382(5)$ & $\mathrm{N}(1)-\mathrm{C}(2)$ & $1.332(4)$ \\
\hline $\mathrm{C}(1)-\mathrm{C}\left(1 \_1\right)$ & $1.351(7)$ & & \\
\hline $\mathrm{C}(2)-\mathrm{N}(1)-\mathrm{C}(1)$ & $108.3(3)$ & $\mathrm{N}(1)-\mathrm{C}(2)-\mathrm{N}\left(1 \_1\right)$ & $108.9(4)$ \\
\hline $\mathrm{N}(1)-\mathrm{C}(1)-\mathrm{C}(1 \quad 1)$ & $107.21(19)$ & & \\
\hline
\end{tabular}

\section{Conclusions}

In the framework of the hugely investigated chemistry of NHC ligands, the reactivity with high valent metal halides has been relatively little developed. In addition and surprisingly, very few examples of NHC complexes of niobium and tantalum have been reported up to now, despite the increasing interest that especially the halides of these metals have attracted. Herein we have described the synthesis and the structural characterization (X-ray and DFT results) of the complexes of a bulky, monodentate NHC ligand with niobium and tantalum pentahalides, showing that the products are stable and tractable materials. In particular, we have presented the unprecedented crystallographic characterization of a Ta complex with a monodentate NHC. Experimental and computational outcomes agree in that the reactions proceed through the intermediacy of ionic species in the cases of the bulkier halides, probably due to kinetic factors favouring the initial combination of one NHC unit with the dimeric metal frame.

\section{Experimental}

\section{General}

Warning: the metal reactants used in this work are highly moisture-sensitive, thus rigorously anhydrous conditions were required for the reaction procedures. The reaction vessels were oven dried at $150{ }^{\circ} \mathrm{C}$ prior to use, evacuated $\left(10^{-2} \mathrm{mmHg}\right)$ and then filled with argon. $\mathrm{NbF}_{5}(99.5 \%)$ and $\mathrm{TaF}_{5}(99 \%)$ were purchased from Apollo Sci., sublimed and stored under argon atmosphere in sealed glass tubes. $\mathrm{NbCl}_{5}(99+\%)$ and $\mathrm{TaCl}_{5}(99.9 \%)$ were purchased from Strem and stored under argon in sealed glass tubes. $\mathrm{NbBr}_{5}, \mathrm{TaBr}_{5}{ }^{29}$ and the NHC ligands ${ }^{14,30}$ were prepared according to the literature by using organic reactants (Apollo Sci.) of the highest purity available, and then stored under argon in sealed glass tubes. Solvents (Sigma Aldrich) were distilled from appropriate drying agents before use. Infrared spectra were recorded at $298 \mathrm{~K}$ on a FT IR-Perkin Elmer Spectrometer, equipped with UATR sampling accessory. Unless otherwise specified, NMR spectra were 
recorded at $298 \mathrm{~K}$ on a Bruker Avance II DRX400 instrument equipped with a BBFO broadband probe. The chemical shifts for ${ }^{1} \mathrm{H}$ and ${ }^{13} \mathrm{C}$ were referenced to the non-deuterated aliquot of the solvent; the chemical shifts for ${ }^{93} \mathrm{Nb}$ were referenced to external $\left[\mathrm{NEt}_{4}\right]\left[\mathrm{NbCl}_{6}\right]$; the chemical shifts for ${ }^{19} \mathrm{~F}$ were referenced to external $\mathrm{CFCl}_{3}$. The ${ }^{1} \mathrm{H}$ and ${ }^{13} \mathrm{C}$ NMR spectra were assigned with the assistance of ${ }^{1} \mathrm{H},{ }^{13} \mathrm{C}$ correlation measured through $g s-\mathrm{HSQC}$ and $g s-\mathrm{HMBC}$ experiments, and are reported with reference to Chart $1 .{ }^{31}$ NMR resonances due to minor amounts of secondary products are italicized. Carbon, hydrogen and nitrogen analyses were performed on a Carlo Erba mod. 1106 instrument. Chloride and bromide were determined by the Mohr method ${ }^{32}$ on solutions prepared by dissolution of the solid in aqueous $\mathrm{KOH}$ at boiling temperature, followed by cooling to room temperature and addition of $\mathrm{HNO}_{3}$ up to neutralization. The metal $(\mathrm{M}=\mathrm{Nb}$, Ta) was analyzed as $\mathrm{M}_{2} \mathrm{O}_{5}$, obtained by hydrolysis of the samples followed by calcination in a platinum crucible.<smiles></smiles>

Chart 1. Numbering of carbon atoms for ${ }^{1} \mathrm{H}$ and ${ }^{13} \mathrm{C}$ assignments

Synthesis and isolation of $\mathrm{NbX}_{5}(\mathrm{Ipr})(\mathrm{X}=\mathrm{F}, 2 ; \mathrm{Br}, 3)$ and $\mathbf{T a X}_{\mathbf{5}}(\mathrm{Ipr})(\mathrm{X}=\mathbf{F}, \mathbf{4} ; \mathbf{C l}, \mathbf{5} ; \mathbf{B r}, \mathbf{6})$. General procedure: a solution of Ipr in toluene (ca. $15 \mathrm{~mL}$ ) was treated with the appropriate metal halide. The mixture was stirred at $80^{\circ} \mathrm{C}$ for $24 \mathrm{~h}$, then pentane $(30$ $\mathrm{mL}$ ) was added. The resulting precipitate was isolated and dried in vacuo. NMR samples were prepared as follows: the metal halide $(0.30 \mathrm{mmol})$ was added to a solution of Ipr $(0.30 \mathrm{mmol})$ in deuterated solvent $(1.5 \mathrm{~mL})$, and the mixture was stirred at ca. 80 ${ }^{\circ} \mathrm{C}$ for $18 \mathrm{~h}$. The resulting solution was allowed to cool to room temperature, then an aliquot was analyzed. X-ray quality crystals of 6 were obtained by setting aside a toluene reaction mixture, layered with pentane, at $-30{ }^{\circ} \mathrm{C}$.

$\mathbf{N b F}_{5}$ (Ipr), 2. Orange solid, $54 \%$ yield from $\mathrm{NbF}_{5}(80 \mathrm{mg}, 0.426$ $\mathrm{mmol})$ and Ipr $(166 \mathrm{mg}, 0.427 \mathrm{mmol})$. Anal. Calcd. for $\mathrm{C}_{27} \mathrm{H}_{36} \mathrm{~F}_{5} \mathrm{~N}_{2} \mathrm{Nb}$ : $\mathrm{C}, 56.25 ; \mathrm{H}, 6.29 ; \mathrm{N}, 4.90 ; \mathrm{Nb}, 16.12$. Found: $\mathrm{C}$, 56.13; H, 6.37; N, 4.81; Nb, 16.28. IR (solid state): $2980 \mathrm{~m}, 2933 \mathrm{w}$, $2875 \mathrm{w}, 1541 \mathrm{w}-\mathrm{m}, 1465 \mathrm{~m}-\mathrm{s}, 1432 \mathrm{w}, 1398 \mathrm{w}, 1384 \mathrm{w}, 1363 \mathrm{w}$, $1323 \mathrm{~m}, 1260 \mathrm{w}, 1200 \mathrm{w}-\mathrm{m}, 1143 \mathrm{w}, 1117 \mathrm{~m}, 1062 \mathrm{~m}, 935 \mathrm{~m}-\mathrm{s}, 848 \mathrm{~m}$, $804 \mathrm{~s}, 762 \mathrm{~s}, 676 \mathrm{vs} \mathrm{cm}^{-1} .{ }^{1} \mathrm{H}$ NMR $\left(\mathrm{C}_{7} \mathrm{D}_{8}\right): \delta=7.27$ (m, $\left.2 \mathrm{H}, \mathrm{C} 6-\mathrm{H}\right)$; 7.10 (m, 4 H, C5-H); 6.68 (s, $2 \mathrm{H}, \mathrm{C} 2-\mathrm{H}) ; 2.90$ (sept, ${ }^{3} \mathrm{~J}_{\mathrm{HH}}=6.85$ $\mathrm{Hz}, 2 \mathrm{H}, \mathrm{CHMe}) ; 1.30\left(\mathrm{~d},{ }^{3} \mathrm{~J}_{\mathrm{HH}}=6.85 \mathrm{~Hz}, 12 \mathrm{H}, \mathrm{Me}\right) ; 1.17 \mathrm{ppm}(\mathrm{d}$, $\left.{ }^{3} \mathrm{~J}_{\mathrm{HH}}=6.85 \mathrm{~Hz}, 12 \mathrm{H}, \mathrm{Me}\right) .{ }^{13} \mathrm{C} \mathrm{NMR}\left\{{ }^{1} \mathrm{H}\right\}\left(\mathrm{C}_{7} \mathrm{D}_{8}\right): \delta=145.7$ (C4); 134.7 (C3); 130.5 (C6); 124.3 (C5); 123.7 (C2); $28.9\left(\mathrm{CHMe}_{2}\right)$, 25.8, $22.2 \mathrm{ppm}(\mathrm{Me}) .{ }^{93} \mathrm{Nb} \mathrm{NMR}\left(\mathrm{C}_{7} \mathrm{D}_{8}\right): \delta=-1447 \mathrm{ppm}\left(\Delta v^{1 / 2}=\right.$ $\left.1.0 \cdot 10^{4} \mathrm{~Hz}\right) .{ }^{19} \mathrm{~F}$ NMR $\left(\mathrm{C}_{7} \mathrm{D}_{8}\right): \delta=131.4 \mathrm{ppm}\left(\Delta v^{1 / 2}=100 \mathrm{~Hz}\right) \cdot{ }^{19} \mathrm{~F}$ $\operatorname{NMR}\left(\mathrm{C}_{7} \mathrm{D}_{8}, 213 \mathrm{~K}\right): \delta=129.7 \mathrm{ppm}\left(\Delta v^{1 / 2}=60 \mathrm{~Hz}\right)$.

$\mathrm{NbBr}_{5}$ (Ipr), 3. Dark-red solid, $62 \%$ yield from $\mathrm{NbBr}_{5}(200 \mathrm{mg}$, $0.406 \mathrm{mmol})$ and $\mathrm{Ipr}(160 \mathrm{mg}, 0.412 \mathrm{mmol})$. Anal. Calcd. for $\mathrm{C}_{27} \mathrm{H}_{36} \mathrm{Br}_{5} \mathrm{~N}_{2} \mathrm{Nb}$ : C, 36.81; H, 4.12; N, 3.18; Br, 45.35; Nb, 10.55 . Found: C, 36.72; H, 4.16; N, 3.11; Br, 45.03; Nb, 10.38. IR (solid state): $2950 \mathrm{w}, 2869 \mathrm{w}, 1533 \mathrm{w}, 1463 \mathrm{~m}, 1445 \mathrm{~m}-\mathrm{sh}, 1386 \mathrm{w}, 1365 \mathrm{w}$, $1330 \mathrm{w}, 1204 \mathrm{w}, 1181 \mathrm{w}, 1059 \mathrm{~m}, 937 \mathrm{~m}, 867 \mathrm{w}-\mathrm{m}, 800 \mathrm{~s}, 755 \mathrm{~s}, 681 \mathrm{~m}$ $\mathrm{cm}^{-1} .{ }^{1} \mathrm{H}$ NMR $\left(\mathrm{C}_{6} \mathrm{D}_{6}\right): \delta=7.27$ (m-br, $\left.2 \mathrm{H}, \mathrm{C} 6-\mathrm{H}\right) ; 7.19$ (m-br, $\left.{ }^{3} \mathrm{~J}_{\mathrm{HH}}=7.2 \mathrm{~Hz}, 4 \mathrm{H}, \mathrm{C} 5-\mathrm{H}\right) ; 6.63(\mathrm{~s}, 2 \mathrm{H}, \mathrm{C} 2-\mathrm{H}) ; 3.02(\mathrm{br}, 2 \mathrm{H}$,
$\mathrm{CHMe}_{2}$ ); 1.55 (br, $12 \mathrm{H}, \mathrm{Me}$ ); $1.02 \mathrm{ppm}$ (br, $\left.12 \mathrm{H}, \mathrm{Me}\right) .{ }^{13} \mathrm{C}$ $\operatorname{NMR}\left\{{ }^{1} \mathrm{H}\right\}\left(\mathrm{C}_{6} \mathrm{D}_{6}\right): \delta=146.1(\mathrm{C} 4) ; 134.2(\mathrm{C} 3) ; 131.4$ (C6); 124.5 $(\mathrm{C} 2+\mathrm{C} 5) ; 29.1\left(\mathrm{CHMe}_{2}\right) ; 26.3,22.5 \mathrm{ppm}(\mathrm{Me}) .{ }^{93} \mathrm{Nb} \mathrm{NMR}$ $\left(\mathrm{C}_{6} \mathrm{D}_{6}\right): \delta=-65 \mathrm{ppm}\left(\Delta v^{1 / 2}=1.3 \cdot 10^{4} \mathrm{~Hz}\right)$.

$\mathrm{TaF}_{5}$ (Ipr), 4. Light-yellow solid, $47 \%$ yield from $\mathrm{TaF}_{5}(120 \mathrm{mg}$, $0.435 \mathrm{mmol})$ and $\mathrm{Ipr}(170 \mathrm{mg}, 0.437 \mathrm{mmol})$. Anal. Calcd. for $\mathrm{C}_{27} \mathrm{H}_{36} \mathrm{~F}_{5} \mathrm{~N}_{2}$ Ta: $\mathrm{C}$, 48.80; H, 5.46; N, 4.22; Ta, 27.23. Found: $\mathrm{C}$, 48.62; H, 5.54; N, 4.13; Ta, 27.10. IR (solid state): $3179 \mathrm{w}, 2969 \mathrm{w}$, $2933 \mathrm{w}, 2875 \mathrm{w}-\mathrm{m}, 1596 \mathrm{w}, 1477 \mathrm{w}, 1465 \mathrm{~m}, 1446 \mathrm{~m}, 1403 \mathrm{~m}, 1385 \mathrm{~m}$, $1364 \mathrm{w}-\mathrm{m}, 1351 \mathrm{w}, 1327 \mathrm{~m}, 1294 \mathrm{w}, 1205 \mathrm{~m}, 1183 \mathrm{w}, 1117 \mathrm{~m}, 1061 \mathrm{~m}$, 936m, 803s, 757vs, 706w, 690s cm ${ }^{-1} .{ }^{1} \mathrm{H}$ NMR $\left(\mathrm{C}_{7} \mathrm{D}_{8}\right): \delta=7.24$ (m, 2 H, C6-H); 7.12 (m, 4 H, C5-H); 6.52 (s, 2 H, C2-H); 2.71 (m, $2 \mathrm{H}, \mathrm{CHMe} 2) ; 1.37\left(\mathrm{~d},{ }^{3} \mathrm{~J}_{\mathrm{HH}}=6.2 \mathrm{~Hz}, 12 \mathrm{H}, \mathrm{Me}\right) ; 1.04 \mathrm{ppm}\left(\mathrm{d},{ }^{3} \mathrm{~J}_{\mathrm{HH}}\right.$ $=6.7 \mathrm{~Hz}, 12 \mathrm{H}, \mathrm{Me}) .{ }^{13} \mathrm{C} \mathrm{NMR}\left\{{ }^{1} \mathrm{H}\right\}\left(\mathrm{C}_{7} \mathrm{D}_{8}\right): \delta=145.5(\mathrm{C} 4) ; 134.5$ (C3); 130.4 (C6); 123.5 (C2 + C5); $28.8\left(\mathrm{CHMe}_{2}\right) ; 25.6,22.0 \mathrm{ppm}$ (Me). ${ }^{19} \mathrm{~F} \mathrm{NMR}\left(\mathrm{C}_{7} \mathrm{D}_{8}\right): \delta=81.9 \mathrm{ppm}\left(\Delta v^{1 / 2}=6 \cdot 10^{2} \mathrm{~Hz}\right)$.

TaCl$_{5}$ (Ipr), 5. Yellow solid, 59\% yield from $\mathrm{TaCl}_{5}(120 \mathrm{mg}, 0.335$ $\mathrm{mmol}$ ) and Ipr (135 mg, $0.347 \mathrm{mmol})$. Anal. Calcd. for $\mathrm{C}_{27} \mathrm{H}_{36} \mathrm{Cl}_{5} \mathrm{~N}_{2}$ Ta: C, 43.42; H, 4.86; N, 3.75; Cl, 23.74; Ta, 24.23. Found: C, 43.26; H, 4.82; N, 3.65; Cl, 23.50; Ta, 24.40. IR (solid state): $2967 \mathrm{~m}, 2930 \mathrm{w}, 2869 \mathrm{w}, 1637 \mathrm{w}, 1465 \mathrm{~m}, 1444 \mathrm{~m}, 1386 \mathrm{~m}$, $1364 \mathrm{w}-\mathrm{m}, 1327 \mathrm{w}, 1200 \mathrm{w}, 1180 \mathrm{w}, 1059 \mathrm{~m}, 936 \mathrm{~m}, 891 \mathrm{~m}, 800 \mathrm{~s}$, $758 \mathrm{~s}, 729 \mathrm{~m}, 696 \mathrm{~m} \mathrm{~cm}^{-1} .{ }^{1} \mathrm{H}$ NMR $\left(\mathrm{C}_{7} \mathrm{D}_{8}\right): \delta=7.13(\mathrm{~m}, 2 \mathrm{H}, \mathrm{C} 6-$ $\mathrm{H}) ; 7.01(\mathrm{~m}, 4 \mathrm{H}, \mathrm{C} 5-\mathrm{H}) ; 6.82(\mathrm{~s}, 2 \mathrm{H}, \mathrm{C} 2-\mathrm{H}) ; 2.86\left(\mathrm{sept},{ }^{3} \mathrm{~J}_{\mathrm{HH}}=\right.$ $6.68 \mathrm{~Hz}, 2 \mathrm{H}, \mathrm{CHMe}) ; 1.35\left(\mathrm{~d},{ }^{3} \mathrm{~J}_{\mathrm{HH}}=6.68 \mathrm{~Hz}, 12 \mathrm{H}, \mathrm{Me}\right) ; 1.19$ ppm $\left(\mathrm{d},{ }^{3} \mathrm{~J}_{\mathrm{HH}}=7.15 \mathrm{~Hz}, 12 \mathrm{H}, \mathrm{Me}\right) .{ }^{13} \mathrm{C} \mathrm{NMR}\left\{{ }^{1} \mathrm{H}\right\}\left(\mathrm{C}_{7} \mathrm{D}_{8}\right): \delta=$ 189.7 (C1); 145.9 (C4); 137.2 (C3); 132.2 (C6); 125.7 (C5); 125.4 (C2); $29.2\left(\mathrm{CHMe}_{2}\right) ; 26.2,21.9 \mathrm{ppm}(\mathrm{Me})$.

$\mathrm{TaBr}_{5}$ (Ipr), 6. Yellow solid, 64\% yield from $\mathrm{TaBr}_{5}(240 \mathrm{mg}, 0.413$ $\mathrm{mmol})$ and Ipr (162 $\mathrm{mg}, 0.417 \mathrm{mmol})$. Anal. Calcd. for $\mathrm{C}_{27} \mathrm{H}_{36} \mathrm{Br}_{5} \mathrm{~N}_{2}$ Ta: $\mathrm{C}, 33.46 ; \mathrm{H}, 3.74 ; \mathrm{N}, 2.89 ; \mathrm{Br}, 41.23$; Ta, 18.67. Found: C, 33.30; H, 3.81; N, 2.81; Br, 41.09; Ta, 18.55. IR (solid state): $3106 \mathrm{w}, 2964 \mathrm{~s}, 2927 \mathrm{~m}, 2868 \mathrm{~m}, 1584 \mathrm{w}, 1539 \mathrm{w}-\mathrm{m}, 1458 \mathrm{~m}-\mathrm{s}$, $1442 \mathrm{w}, 1386 \mathrm{~m}, 1365 \mathrm{~m}, 1325 \mathrm{~m}, 1198 \mathrm{~m}, 1182 \mathrm{w}-\mathrm{m}, 1097 \mathrm{~m}, 1058 \mathrm{~m}$, 934w, 851w, 799s, 752s, 676m cm ${ }^{-1} .{ }^{1} \mathrm{H}$ NMR $\left(\mathrm{C}_{7} \mathrm{D}_{8}\right): \delta=7.30-$ $7.02(\mathrm{~m}, \mathrm{C} 6-\mathrm{H}+\mathrm{C} 5-\mathrm{H}) ; 6.65,6.48(\mathrm{~s}, \mathrm{C} 2-\mathrm{H}) ; 3.10,2.96(\mathrm{~m}$, $\mathrm{CHMe}) ; 1.52,1.28,1.22,1.06 \mathrm{ppm}(\mathrm{d}, \mathrm{Me})$. Isomer ratio $2: 1 .{ }^{13} \mathrm{C}$ $\mathrm{NMR}\left\{{ }^{1} \mathrm{H}\right\}\left(\mathrm{C}_{7} \mathrm{D}_{8}\right): \delta=188.3(\mathrm{C} 1) ; 146.7,146.1(\mathrm{C} 4) ; 137.7(\mathrm{C} 3)$; 130.9 (C6); 125.5 (C5); 124.2, 123.2 (C2); 28.9, $28.4\left(\mathrm{CHMe}_{2}\right)$; 25.6, 24.4, 23.1, $22.9 \mathrm{ppm}(\mathrm{Me})$.

\section{NMR studies.}

1) Reactions of $\mathrm{MX}_{5}$ with Ipr in 1:1 molar ratio: detection of $\left[\mathbf{N b X}_{\mathbf{6}}\right]^{-}(\mathbf{X}=\mathbf{C l}, \mathbf{B r})$. General procedure: the metal halide $(0.30$ $\mathrm{mmol})$ was added to a solution of Ipr $(0.30 \mathrm{mmol})$ in deuterated solvent $(1.5 \mathrm{~mL})$. The mixture was stirred at room temperature. Aliquots were withdrawn from the reaction solution at different times and then NMR analyzed. The reaction involving $\mathrm{TaCl}_{5}$ required prolonged heating at ca. $80{ }^{\circ} \mathrm{C}$ in order to complete the conversion into the final product.

A) From $\mathrm{NbCl}_{5} / \mathrm{Ipr} .{ }^{1} \mathrm{H}$ NMR $\left(\mathrm{C}_{6} \mathrm{D}_{6}\right.$, after 30 minutes $)$ : $\delta=7.26$ (m, 2 H, C6-H); 7.18 (m, 4 H, C5-H); 6.65 (s, 2 H, C2-H); 2.99 (sept, $\left.{ }^{3} \mathrm{~J}_{\mathrm{HH}}=6.68 \mathrm{~Hz}, 2 \mathrm{H}, \mathrm{CHMe}\right) ; 1.52\left(\mathrm{~d},{ }^{3} \mathrm{~J}_{\mathrm{HH}}=6.68 \mathrm{~Hz}, 12 \mathrm{H}\right.$, $\mathrm{Me}) ; 1.03 \mathrm{ppm}\left(\mathrm{d},{ }^{3} \mathrm{~J}_{\mathrm{HH}}=7.15 \mathrm{~Hz}, 12 \mathrm{H}, \mathrm{Me}\right) .{ }^{93} \mathrm{Nb} \mathrm{NMR}\left(\mathrm{C}_{6} \mathrm{D}_{6}\right.$, after $30 \mathrm{~min}): \delta=8\left(\Delta v^{1 / 2}=4.5 \cdot 10^{2} \mathrm{~Hz}, \mathrm{NbCl}_{6}{ }^{-}\right) ;-335 \mathrm{ppm}\left(\Delta \mathrm{v}^{1 / 2}\right.$ $\left.=5 \cdot 10^{3} \mathrm{~Hz}\right) .{ }^{1} \mathrm{H} \mathrm{NMR}\left(\mathrm{C}_{6} \mathrm{D}_{6}\right.$, after $\left.72 \mathrm{~h}\right): \delta=7.29\left(\mathrm{t},{ }^{3} \mathrm{~J}_{\mathrm{HH}}=7.8 \mathrm{~Hz}\right.$, $2 \mathrm{H}, \mathrm{C} 6-\mathrm{H}), 7.18\left(\mathrm{~d},{ }^{3} \mathrm{~J}_{\mathrm{HH}}=7.8 \mathrm{~Hz}, 4 \mathrm{H}, \mathrm{C} 5-\mathrm{H}\right), 6.65(\mathrm{~s}, 2 \mathrm{H}, \mathrm{C} 2-$ $\mathrm{H}), 2.98\left(\mathrm{sept},{ }^{3} \mathrm{~J}_{\mathrm{HH}}=5.87 \mathrm{~Hz}, 2 \mathrm{H}, \mathrm{CHMe}\right), 1.54\left(\mathrm{~d},{ }^{3} \mathrm{~J}_{\mathrm{HH}}=5.87\right.$ $\left.\mathrm{Hz}, 12 \mathrm{H}, \mathrm{CHMe} e_{2}\right), 1.04 \mathrm{ppm}\left(\mathrm{d},{ }^{3} \mathrm{~J}_{\mathrm{HH}}=6.99 \mathrm{~Hz}, 12 \mathrm{H}, \mathrm{CHMe} e_{2}\right.$. ${ }^{93} \mathrm{Nb}$ NMR $\left(\mathrm{C}_{6} \mathrm{D}_{6}\right.$, after $\left.72 \mathrm{~h}\right): \delta=-318 \mathrm{ppm}\left(\Delta v^{1 / 2}=2.0 \cdot 10^{3} \mathrm{~Hz}\right)$.

B) From $\mathrm{NbF}_{5} / \mathrm{Ipr} .{ }^{1} \mathrm{H}$ NMR $\left(\mathrm{C}_{7} \mathrm{D}_{8}\right.$, after $\left.30 \mathrm{~min}\right): \delta={ }^{1} \mathrm{H}$ NMR $\left(\mathrm{C}_{7} \mathrm{D}_{8}\right.$, after $\left.30 \mathrm{~min}\right): \delta=7.34(\mathrm{~m}, 2 \mathrm{H}, \mathrm{C} 6-\mathrm{H}) ; 7.20$ (m, $4 \mathrm{H}, \mathrm{C} 5-$ $\mathrm{H}) ; 6.59$ (s, $2 \mathrm{H}, \mathrm{C} 2-\mathrm{H}) ; 2.82\left(\mathrm{sept},{ }^{3} \mathrm{~J}_{\mathrm{HH}}=6.85 \mathrm{~Hz}, 2 \mathrm{H}, \mathrm{CHMe}\right.$ ); $1.46\left(\mathrm{~d},{ }^{3} \mathrm{~J}_{\mathrm{HH}}=6.85 \mathrm{~Hz}, 12 \mathrm{H}, \mathrm{Me}\right) ; 1.11 \mathrm{ppm}\left(\mathrm{d},{ }^{3} \mathrm{~J}_{\mathrm{HH}}=6.85 \mathrm{~Hz}\right.$, $12 \mathrm{H}, \mathrm{Me}) .{ }^{93} \mathrm{Nb} \mathrm{NMR}\left(\mathrm{C}_{7} \mathrm{D}_{8}\right.$, after $\left.30 \mathrm{~min}\right): \delta=-1447\left(\Delta v^{1 / 2}=\right.$ $\left.1.0 \cdot 10^{4} \mathrm{~Hz}\right) ;-1549 \mathrm{ppm}\left(\Delta v^{1 / 2}=7.0 \cdot 10^{2} \mathrm{~Hz}, \mathrm{NbF}_{6}^{-}\right) .{ }^{19} \mathrm{~F}$ NMR $\left(\mathrm{C}_{7} \mathrm{D}_{8}\right.$, after $\left.30 \mathrm{~min}\right): \delta=129.4\left(\Delta v^{1 / 2}=90 \mathrm{~Hz}\right) ; 103.1\left(\mathrm{~m}, \mathrm{NbF}_{6}^{-}\right.$, 
traces). ${ }^{1} \mathrm{H}$ NMR $\left(\mathrm{C}_{7} \mathrm{D}_{8}\right.$, after $\left.18 \mathrm{~h}\right): \delta=7.27(\mathrm{~m}, 2 \mathrm{H}, \mathrm{C} 6-\mathrm{H}) ; 7.10$ $(\mathrm{m}, 4 \mathrm{H}, \mathrm{C} 5-\mathrm{H}) ; 6.68(\mathrm{~s}, 2 \mathrm{H}, \mathrm{C} 2-\mathrm{H}) ; 2.90\left(\mathrm{sept},{ }^{3} \mathrm{~J}_{\mathrm{HH}}=6.85 \mathrm{~Hz}, 2\right.$ $\left.\mathrm{H}, \mathrm{C} H \mathrm{Me}_{2}\right) ; 1.30\left(\mathrm{~d},{ }^{3} \mathrm{~J}_{\mathrm{HH}}=6.85 \mathrm{~Hz}, 12 \mathrm{H}, \mathrm{Me}\right) ; 1.17 \mathrm{ppm}\left(\mathrm{d},{ }^{3} \mathrm{~J}_{\mathrm{HH}}\right.$ $=6.85 \mathrm{~Hz}, 12 \mathrm{H}, \mathrm{Me}) .{ }^{93} \mathrm{Nb} \mathrm{NMR}\left(\mathrm{C}_{7} \mathrm{D}_{8}\right.$, after $\left.18 \mathrm{~h}\right): \delta=-1447$ $\left(\Delta v^{1 / 2}=1.0 \cdot 10^{4} \mathrm{~Hz}\right)$ ppm. ${ }^{19} \mathrm{~F}$ NMR $\left(\mathrm{C}_{7} \mathrm{D}_{8}\right.$, after $\left.18 \mathrm{~h}\right): \delta=131.4$ $\operatorname{ppm}\left(\Delta v^{1 / 2}=100 \mathrm{~Hz}\right)$

C) From $\mathrm{NbBr}_{5} / \mathrm{Ipr}$. ${ }^{1} \mathrm{H}$ NMR $\left(\mathrm{C}_{6} \mathrm{D}_{6}\right.$, after $\left.30 \mathrm{~min}\right)$ : $\delta=7.24$ (m-br, $2 \mathrm{H}, \mathrm{C} 6-\mathrm{H}) ; 7.06\left(\mathrm{~m}-\mathrm{br},{ }^{3} \mathrm{~J}_{\mathrm{HH}}=7.2 \mathrm{~Hz}, 4 \mathrm{H}, \mathrm{C} 5-\mathrm{H}\right) ; 6.54(\mathrm{~s}, 2 \mathrm{H}$, $\mathrm{C} 2-\mathrm{H}) ; 2.93$ (br, $2 \mathrm{H}, \mathrm{C} H \mathrm{Me}_{2}$ ); 1.44 (br, $12 \mathrm{H}, \mathrm{Me}$ ); 0.92 ppm (br, $12 \mathrm{H}, \mathrm{Me}) .{ }^{93} \mathrm{Nb} \mathrm{NMR}\left(\mathrm{C}_{6} \mathrm{D}_{6}\right.$, after $\left.30 \mathrm{~min}\right): \delta=735\left(\Delta v^{1 / 2}=\right.$ $\left.1.0 \cdot 10^{2} \mathrm{~Hz}, \mathrm{NbBr}_{6}{ }^{-}\right) ;-57 \mathrm{ppm}\left(\Delta v^{1 / 2}=1.2 \cdot 10^{4} \mathrm{~Hz}\right) .{ }^{1} \mathrm{H}$ NMR $\left(\mathrm{C}_{6} \mathrm{D}_{6}\right.$, after $\left.72 \mathrm{~h}\right): \delta=7.27(\mathrm{~m}-\mathrm{br}, 2 \mathrm{H}, \mathrm{C} 6-\mathrm{H}) ; 7.19\left(\mathrm{~m}-\mathrm{br},{ }^{3} \mathrm{~J}_{\mathrm{HH}}=\right.$ $7.2 \mathrm{~Hz}, 4 \mathrm{H}, \mathrm{C} 5-\mathrm{H}) ; 6.63$ (s, $2 \mathrm{H}, \mathrm{C} 2-\mathrm{H}) ; 3.02$ (br, $2 \mathrm{H}, \mathrm{CHMe}$ ); 1.55 (br, $12 \mathrm{H}, \mathrm{Me}) ; 1.02 \mathrm{ppm}(\mathrm{br}, 12 \mathrm{H}, \mathrm{Me}) .{ }^{93} \mathrm{Nb} \mathrm{NMR}\left(\mathrm{C}_{6} \mathrm{D}_{6}\right.$, after $72 \mathrm{~h}): \delta=-65 \mathrm{ppm}\left(\Delta \mathrm{v}^{1 / 2}=1.3 \cdot 10^{4} \mathrm{~Hz}\right)$.

D) From $\mathrm{TaF}_{5} / \mathrm{Ipr} .{ }^{1} \mathrm{H}$ NMR $\left(\mathrm{C}_{7} \mathrm{D}_{8}\right.$, after $\left.10 \mathrm{~min}\right): \delta=7.24(\mathrm{~m}, 2 \mathrm{H}$, C6-H); 7.12 (m, 4 H, C5-H); 6.52 (s, 2 H, C2-H); 2.71 (br, $2 \mathrm{H}$, $\left.\mathrm{C} H \mathrm{Me}_{2}\right) ; 1.37\left(\mathrm{~d},{ }^{3} \mathrm{~J}_{\mathrm{HH}}=6.2 \mathrm{~Hz}, 12 \mathrm{H}, \mathrm{Me}\right) ; 1.04 \mathrm{ppm}\left(\mathrm{d},{ }^{3} \mathrm{~J}_{\mathrm{HH}}=\right.$ $6.7 \mathrm{~Hz}, 12 \mathrm{H}, \mathrm{Me}) .{ }^{19} \mathrm{~F}$ NMR $\left(\mathrm{C}_{7} \mathrm{D}_{8}\right.$, after $\left.10 \mathrm{~min}\right): \delta=82.1 \mathrm{ppm}$ $\left(\Delta v^{1 / 2}=6 \cdot 10^{2} \mathrm{~Hz}\right)$

E) From $\mathrm{TaCl}_{5} / \mathrm{Ipr} .{ }^{1} \mathrm{H}$ NMR $\left(\mathrm{C}_{7} \mathrm{D}_{8}\right.$, after $\left.30 \mathrm{~min}\right): \delta=7.18(\mathrm{~m}, 2$ H, C6-H); 7.01 (m, 4 H, C5-H); 6.45 (s, 2 H, C2-H); 2.90 (sept, $\left.{ }^{3} \mathrm{~J}_{\mathrm{HH}}=6.68 \mathrm{~Hz}, 2 \mathrm{H}, \mathrm{CHMe}\right) ; 1.41\left(\mathrm{~d},{ }^{3} \mathrm{~J}_{\mathrm{HH}}=6.68 \mathrm{~Hz}, 12 \mathrm{H}, \mathrm{Me}\right)$; $1.01 \mathrm{ppm}\left(\mathrm{d},{ }^{3} \mathrm{~J}_{\mathrm{HH}}=7.15 \mathrm{~Hz}, 12 \mathrm{H}, \mathrm{Me}\right) .{ }^{13} \mathrm{C} \mathrm{NMR}\left\{{ }^{1} \mathrm{H}\right\}\left(\mathrm{C}_{7} \mathrm{D}_{8}\right.$, after 30 minutes): $\delta=189.7$ (C1); 145.6 (C4); 137.1 (C3); 130.6 (C6); 125.0 (C5); 123.9 (C2); $28.7\left(\mathrm{CHMe}_{2}\right) ; 25.5,22.6 \mathrm{ppm}(\mathrm{Me})$ ${ }^{1} \mathrm{H}$ NMR $\left(\mathrm{C}_{7} \mathrm{D}_{8}\right.$, after $20 \mathrm{~h}$ heating): $\delta=7.13(\mathrm{~m}, 2 \mathrm{H}, \mathrm{C} 6-\mathrm{H}) ; 7.01$ $(\mathrm{m}, 4 \mathrm{H}, \mathrm{C} 5-\mathrm{H}) ; 6.82$ (s, $2 \mathrm{H}, \mathrm{C} 2-\mathrm{H}) ; 2.81\left(\mathrm{sept},{ }^{3} \mathrm{~J}_{\mathrm{HH}}=6.68 \mathrm{~Hz}, 2\right.$ $\left.\mathrm{H}, \mathrm{C} H \mathrm{Me}_{2}\right) ; 1.38\left(\mathrm{~d},{ }^{3} \mathrm{~J}_{\mathrm{HH}}=6.68 \mathrm{~Hz}, 12 \mathrm{H}, \mathrm{Me}\right) ; 1.15 \mathrm{ppm}\left(\mathrm{d},{ }^{3} \mathrm{~J}_{\mathrm{HH}}\right.$ $=7.15 \mathrm{~Hz}, 12 \mathrm{H}, \mathrm{Me}) .{ }^{13} \mathrm{C} \mathrm{NMR}\left\{{ }^{1} \mathrm{H}\right\}\left(\mathrm{C}_{7} \mathrm{D}_{8}\right.$, after 20 h heating): $\delta$ $=189.7$ (C1); 145.9 (C4); 137.2 (C3); 132.2 (C6); 125.7 (C5); $125.4(\mathrm{C} 2) ; 29.2\left(\mathrm{CHMe}_{2}\right) ; 26.2,21.9 \mathrm{ppm}(\mathrm{Me})$.

F) From $\mathrm{TaBr}_{5} / \mathrm{Ipr} .{ }^{1} \mathrm{H}$ NMR $\left(\mathrm{C}_{7} \mathrm{D}_{8}\right.$, after $\left.30 \mathrm{~min}\right): \delta=7.26(\mathrm{~m}, 2$ H, C6-H); 7.13 (m, 4 H, C5-H); 6.60 (s, 2 H, C2-H); 3.11 (sept, $\left.{ }^{3} \mathrm{~J}_{\mathrm{HH}}=6.36 \mathrm{~Hz}, 2 \mathrm{H}, \mathrm{CH} \mathrm{Me}_{2}\right) ; 1.52\left(\mathrm{~d},{ }^{3} \mathrm{~J}_{\mathrm{HH}}=6.85 \mathrm{~Hz}, 12 \mathrm{H}, \mathrm{Me}\right)$; $1.06 \mathrm{ppm}\left(\mathrm{d},{ }^{3} \mathrm{~J}_{\mathrm{HH}}=6.36 \mathrm{~Hz}, 12 \mathrm{H}, \mathrm{Me}\right) .{ }^{13} \mathrm{C} \mathrm{NMR}\left\{{ }^{1} \mathrm{H}\right\}\left(\mathrm{C}_{7} \mathrm{D}_{8}\right.$, after $30 \mathrm{~min}$ ): $\delta=188.3$ (C1); 146.1 (C4);137.7 (C3); 130.9 (C6); 125.5 (C5); 124.2 (C2); $28.9\left(\mathrm{CHMe}_{2}\right) ; 25.6,23.1 \mathrm{ppm}(\mathrm{Me})$.

2) Reactions of $\mathrm{MF}_{5}$ with Ipr in 4:1 molar ratio. General procedure: the metal fluoride $(0.40 \mathrm{mmol})$ was added to a solution of Ipr $(0.40 \mathrm{mmol})$ in deuterated toluene $(2 \mathrm{~mL})$. The mixture was stirred at room temperature. An aliquot was withdrawn from the reaction solution after 15 minutes and then NMR analyzed.

A) From $\mathrm{NbF}_{5} / \mathrm{Ipr}$ (red solution). ${ }^{1} \mathrm{H}$ NMR $\left(\mathrm{C}_{7} \mathrm{D}_{8}\right): \delta=7.29,7.24$ (m, C6-H); 7.14, $7.12(\mathrm{~m}, \mathrm{C} 5-\mathrm{H}) ; 6.54(\mathrm{~s}, \mathrm{C} 2-\mathrm{H}) ; 2.68,2.13(\mathrm{~m}$, $\left.\mathrm{C} H \mathrm{Me}_{2}\right) ; 1.34,1.11\left(\mathrm{~d},{ }^{3} \mathrm{~J}_{\mathrm{HH}}=6.2 \mathrm{~Hz}, \mathrm{Me}\right) ; 1.05,1.04 \mathrm{ppm}\left(\mathrm{d},{ }^{3} \mathrm{~J}_{\mathrm{HH}}\right.$ $=6.7 \mathrm{~Hz}, \mathrm{Me})$. Isomer ratio $c a \cdot 3: 1 .{ }^{19} \mathrm{~F} \mathrm{NMR}\left(\mathrm{C}_{7} \mathrm{D}_{8}\right): \delta=156 \mathrm{ppm}$ $\left(\Delta v^{1 / 2}=7 \cdot 10^{2} \mathrm{~Hz}\right) \cdot{ }^{93} \mathrm{Nb}$ NMR $\left(\mathrm{C}_{7} \mathrm{D}_{8}\right): \delta=-1365\left(\Delta v^{1 / 2}=1 \cdot 10^{4}\right.$ $\mathrm{Hz}) ;-1486 \mathrm{ppm}\left(\Delta v^{1 / 2}=1 \cdot 10^{4} \mathrm{~Hz}\right)$.

B) From $\mathrm{TaF}_{5} / \mathrm{Ipr}$ (orange solution over abundant orange-brown precipitate). ${ }^{19} \mathrm{~F} \mathrm{NMR}\left(\mathrm{C}_{7} \mathrm{D}_{8}\right): \delta=82.0\left(\Delta v^{1 / 2}=3 \cdot 10^{2} \mathrm{~Hz}\right.$, major $)$, $62.2\left(\Delta v^{1 / 2}=20 \mathrm{~Hz}\right), 57.8 \mathrm{ppm}\left(\Delta v^{1 / 2}=\right.$ ca. $\left.30 \mathrm{~Hz}\right)$.

Formation and isolation of $\left[\mathrm{IxylH}_{[}\right]\left[\mathrm{TaF}_{6}\right]$, 7. A solution of Ixy] $(173 \mathrm{mg}, 0.626 \mathrm{mmol})$ in toluene $(10 \mathrm{~mL})$ was treated with $\mathrm{TaF}_{5}$ (170 mg, $0.616 \mathrm{mmol}$ ). The mixture was allowed to stir for $18 \mathrm{~h}$ at room temperature, during which a dark brown precipitate was formed. The solid was dissolved in $\mathrm{CH}_{2} \mathrm{Cl}_{2}(20 \mathrm{~mL})$, and the solution was layered with heptane and settled aside at $-30{ }^{\circ} \mathrm{C}$. Light-brown X-ray quality crystals were collected after one week. Yield $88 \mathrm{mg}, 25 \%$. Anal. Calcd for $\mathrm{C}_{19} \mathrm{H}_{21} \mathrm{~F}_{6} \mathrm{~N}_{2}$ Ta: C, 39.87; $\mathrm{H}$, 3.70; N, 4.89; Ta, 31.62. Found: C, 39.76; H, 3.78; N, 4.75; Ta, 31.30. ${ }^{1} \mathrm{H}$ NMR $\left(\mathrm{CD}_{2} \mathrm{Cl}_{2}\right): \delta=8.65(\mathrm{~s}, 1 \mathrm{H}, \mathrm{C} 1-\mathrm{H}) ; 7.69(\mathrm{~s}, 2 \mathrm{H}$, $\mathrm{C} 2-\mathrm{H}) ; 7.51\left(\mathrm{t}, 3 \mathrm{H},{ }^{3} \mathrm{~J}_{\mathrm{HH}}=7.3 \mathrm{~Hz}, \mathrm{C} 6-\mathrm{H}\right) ; 7.38\left(\mathrm{~d}, 4 \mathrm{H},{ }^{3} \mathrm{~J}_{\mathrm{HH}}=7.8\right.$ $\mathrm{Hz}, \mathrm{C} 5-\mathrm{H}) ; 2.24 \mathrm{ppm}(\mathrm{s}, 12 \mathrm{H}, \mathrm{Me}) .{ }^{19} \mathrm{~F}$ NMR $\left(\mathrm{CD}_{2} \mathrm{Cl}_{2}\right): \delta=38.7$ $\operatorname{ppm}\left(\mathrm{s}, \mathrm{TaF}_{6}^{-}\right)$.

\section{X-ray crystallography.}

Crystal data and collection details for $\mathbf{6}$ and $\mathbf{7}$ are reported in Table 5. The diffraction experiments were carried out on a Bruker APEX II diffractometer equipped with a CCD detector using Mo-Ka radiation. Data were corrected for Lorentz polarization and absorption effects (empirical absorption correction SADABS) ${ }^{33}$ Structures were solved by direct methods and refined by fullmatrix least-squares based on all data using $F^{2}{ }^{34}$ Hydrogen atoms were fixed at calculated positions and refined by a riding model. All non-hydrogen atoms were refined with anisotropic displacement parameters.

Table 5. Crystal data and experimental details for 6 and 7.

\begin{tabular}{|c|c|c|}
\hline & 6 & 7 \\
\hline Formula & $\mathrm{C}_{27} \mathrm{H}_{36} \mathrm{Br}_{5} \mathrm{~N}_{2} \mathrm{Ta}$ & $\mathrm{C}_{19} \mathrm{H}_{21} \mathrm{~F}_{6} \mathrm{~N}_{2} \mathrm{Ta}$ \\
\hline$F w$ & 969.08 & 572.33 \\
\hline $\mathrm{T}, \mathrm{K}$ & $100(2)$ & $100((2)$ \\
\hline$\lambda, \AA$ & 0.71073 & 0.71073 \\
\hline Crystal system & Monoclinic & Orthorhombic \\
\hline Space group & $P 2_{1} / n$ & Pnma \\
\hline$a, \AA$ & $10.232(3)$ & $11.105(2)$ \\
\hline$b, \AA$ & $17.868(5)$ & 16.481(3) \\
\hline$c, \AA$ & $17.892(5)$ & $10.701(2)$ \\
\hline$\beta, \circ$ & $105.018(3)$ & 90 \\
\hline Cell Volume, $\AA^{3}$ & $3159.3(14)$ & $1958.7(7)$ \\
\hline $\mathrm{Z}$ & 4 & 4 \\
\hline$D_{c}, \mathrm{~g} \mathrm{~cm}^{-3}$ & 2.037 & 1.941 \\
\hline$\mu, \mathrm{mm}^{-1}$ & 9.822 & 5.673 \\
\hline $\mathrm{F}(000)$ & 1840 & 1104 \\
\hline Crystal size, mm & $0.22 \times 0.20 \times 0.14$ & $0.16 \times 0.11 \times 0.10$ \\
\hline$\theta$ limits, ${ }^{\circ}$ & $1.64-26.00$ & $2.27-27.00$ \\
\hline Reflections collected & 29725 & 17842 \\
\hline $\begin{array}{l}\text { Independent reflections } \\
0.0609]\end{array}$ & $6217\left[R_{\mathrm{int}}=0.0727\right]$ & $2220\left[R_{\mathrm{int}}=\right.$ \\
\hline Data / restraints / parameters & $6217 / 0 / 316$ & $2220 / 0 / 135$ \\
\hline Goodness of fit on $\mathrm{F}^{2}$ & 1.101 & 1.044 \\
\hline$R_{1}(I>2 \sigma(I))$ & 0.0581 & 0.0238 \\
\hline$w R_{2}$ (all data) & 0.1413 & 0.0549 \\
\hline$R_{1}(I>2 \sigma(I))$ & 0.0581 & 0.0238 \\
\hline Largest diff. peak and hole, e $\AA^{-3}$ & $4.113 /-1.987$ & $1.084 /-0.925$ \\
\hline
\end{tabular}

\section{Computational studies}

The computational geometry optimizations were carried out without symmetry constrains, using the range-separated DFT functional $\omega \mathrm{B} 97 \mathrm{X}^{35}$ in combination with a polarized basis set composed by the $6-31 \mathrm{G}(\mathrm{d}, \mathrm{p})$ set on the light atoms and the ECPbased LANL2TZ(f) and LANL2DZ(d) sets on metal centres and bromine, respectively (BS2). ${ }^{36}$ In some cases, the same functional was used also in combination with the split-valence polarized basis set (with effective core potentials for elements beyond $\mathrm{Kr}$ ) of Ahlrichs and co-workers, indicated as BS1. ${ }^{37}$ The C-PCM implicit solvation model $(\varepsilon=9.08)$ was added. $^{38}$ Some reaction intermediates were finally optimized in vacuo using the hybridGGA EDF2 functional ${ }^{39}$ and the BS3 basis set $\left(6-31 G^{* *}\right.$ plus LANL2DZ on $\mathrm{Nb}) .{ }^{40}$ In all the cases, the "restricted" formalism was applied. The stationary points were characterized by IR simulations (harmonic approximation), from which zero-point vibrational energies and thermal corrections were obtained. ${ }^{41}$ The software used for C-PCM/ $\omega$ B 97 X calculations was Gaussian ' $09,{ }^{42}$ while EDF2 calculations were performed with Spartan ' $08 .{ }^{43}$

Supplementary Material. Figures S1-S9 show the DFT-calculated structures of possible reaction intermediates, while tables S1-S9 contain the relevant bonding parameters; figures S10-S24 show the NMR spectra of the products. Cartesian coordinates of all DFToptimized compounds are collected in a separated .xyz file. CCDC reference numbers 1437953 (6) and 1437954 (7) contain the supplementary crystallographic data for the X-ray studies reported in this paper. These data can be obtained free of charge at 
www.ccdc.cam.ac.uk/conts/retrieving.html (or from the Cambridge Crystallographic Data Centre, 12, Union Road, CambridgeCB2 1EZ, UK; fax: (internat.) +44-1223/336-033; e-mail: deposit@ccdc.cam.ac.uk).

\section{References and Notes}

1 Recent references include: (a) F. Lazreg, F. Nahra and C. S. Cazin, J. Coord. Chem. Rev., 2015, 293-294, 48-79; (b) D. J. Nelson, Eur. J. Inorg. Chem., 2015, 2012-2027; (c) F. Hackenberg and M. Tacke, Dalton Trans., 2014, 43, 8144-8153; (d) J. Broggi, V. Jurcík, O Songis, A. Poater, L. Cavallo, A. M. Z. Slawin and C. S. J. Cazin, J. Am. Chem. Soc., 2013, 135, 4588-4591; (e) J. DePasquale, M. Kumar, M. Zeller and E. T. Papish, Organometallics, 2013, 32, 966-979; (f) K. F. Donnelly, A. Petronilho and M. Albrecht, Chem. Commun., 2013, 49, 1145-1159; (g) L. Oehninger, R. Rubbiani and I. Ott, Dalton Trans., 2013, 3269-3284; (h) H. Diaz Velazquez and F. Verpoort, Chem. Soc. Rev., 2012, 41, 7032-7060; (i) K. M. Hindi, M. J. Panzner, C. A. Tessier, C. L. Cannon and W. J. Youngs, Chem. Rev., 2009, 109, 3859-3884.

(a) S. Bellemin-Laponnaz and S. Dagorne, Chem. Rev., 2014, 114 8747-8774; (b) S. J. Hock, L.-A. Schaper, W. A. Herrmann and F. E. Kühn, Chem. Soc. Rev., 2013, 42, 5073-5089; (c) A. A. Danopoulos, P. Braunstein, M. Wesolek, K. Yu. Monakhov, P. Rabu and V. Robert, Organometallics, 2012, 31, 4102-4105; (d) M. Asay, C. Jones and M. Driess, Chem. Rev., 2011, 111, 354-396; (e) H. Jacobsen, A Correa, A. Poater, C. Costabile and L. Cavallo, Coord. Chem. Rev., 2009, 253, 687-703.

(a) C. A. Dodds, M. D. Spicer and T. Tuttle, Organometallics, 2011, 30, 6262-6269; (b) C. Lorber and L. Vendier, Dalton Trans., 2009, 6972-6984; (c) G. B. Nikiforov, H. W. Roesky, P. G. Jones, J. Magull, A. Ringe and R. B. Oswald, Inorg. Chem., 2008, 47, 21712179; (d) P. Shukla, J. A. Johnson, D. Vidovic, A. H. Cowley and C. D. Abernethy, Chem. Commun., 2004, 360-361.

(a) M. R. Buchmeiser, S. Suman Sen, J. Unold and W. Frey, Angew. Chem. Int. Ed., 2014, 53, 9384-9388; (b) C. D. Abernethy, G. M Codd, M. D. Spicer and M. K. Taylor, J. Am. Chem. Soc., 2003, 125, 1128-1129; (c) W. A. Herrmann, G. M. Lobmaier and M. Elison, J. Organomet. Chem., 1996, 520, 231-234.

M. Bortoluzzi, E. Ferretti, F. Marchetti, G. Pampaloni and S. Zacchini, Chem. Commun., 2014, 50, 4472-4474.

(a) T. R. Helgert, T. K. Hollis, A. G. Oliver, H. U. Valle, Y. Wu and C. E. Webster, Organometallics, 2014, 33, 952-958; (b) L. P. Spencer, C. Beddie, M. B. Hall and M. D. Fryzuk, J. Am. Chem. Soc., 2006, 128, 12531-12543; (c) D. Pugh, J. A. Wright, S. Freeman and A. A. Danopoulos, Dalton Trans., 2006, 775-782; (d) W. A Herrmann, K. Öfele, M. Elison, F. E. Kühn and P. W. Roesky, J. Organomet. Chem., 1994, 480, C7-C9.

A. Spannenberg, H. Fuhrmann, P. Arndt, W. Baumann and R. Kempe, Angew Chem. Int. Ed., 1998, 37, 3363-3365.

A. M. Raspolli Galletti and G. Pampaloni, Coord. Chem. Rev., 2010, 254, 525-536.

(a) S. M. Coman, M. Verziu, A. Tirsoaga, B. Jurca, C. Teodorescu, V. Kuncser, V. I. Parvulescu, G. Scholz and E. Kemnitz, ACS Catal., 2015, 5, 3013-3026; (b) Y. Satoh and Y. Obora, Eur. J. Org. Chem. 2015, 5041-5054; (c) M. E. Wilhelm, M. H. Anthofer, R. M. Reich, V. D'Elia, J.-M. Basset, W. A. Herrmann, M. Cokoja and F. E. Kühn, Catal. Sci. Technol., 2014, 4, 1638-1643; (d) A. Monassier, V. D'Elia, M. Cokoja, H. Dong, J. D. A. Pelletier, J.-M. Basset and F. E. Kühn, ChemCatChem, 2013, 5, 1321-1324; (e) C. Redshaw, M. Walton, L. Clowes, D. L. Hughes, A.-M. Fuller, Y. Chao, A. Walton, V. Sumerin, P. Elo, I. Soshnikov, W. Zhao, and W.-H. Sun, Chem. Eur. J., 2013, 19, 8884-8899; (f) F. Marchetti and G. Pampaloni, Chem Commun., 2012, 48, 635-653, and references therein; (g) F Marchetti, C. Pinzino, S. Zacchini and G. Pampaloni, Angew. Chem Int. Ed., 2010, 49, 5268-5272; (h) K. Fuchibe, T. Kaneko, K. Mori and T. Akiyama, Angew. Chem. Int. Ed., 2009, 48, 8070-8073.

10 A. Doddi, C. Gemel, R. W. Seidel, M. Winter and R. A. Fischer, Polyhedron, 2013, 52, 1103-1108.

11 The pentafluorides of niobium and tantalum have tetranuclear structure in the solid state, ${ }^{12 a}$ while the heavier pentahalides are dinuclear in the solid state. ${ }^{12 \mathrm{~b}-\mathrm{c}}$ All of these compounds will be mentioned by the empirical formulas $\mathrm{MX}_{5}$ throughout this paper.

12 (a) A. J. Edwards, J. Chem. Soc., 1964, 3714-3718; (b) A. F. Wells, Structural Inorganic Chemistry, 5th Edition, Clarendon Press,
Oxford, 1993; (c) K. Habermehl, I. Pantenburg and G. Meyer, Acta Cryst., 2010, E66, i67.

13 IR spectrum (solid state) of Ipr: 3146w, 3063w, 2961s, 2929m, $2868 \mathrm{~m}, 1670 \mathrm{~s}, 1614 \mathrm{~m}, 1537 \mathrm{w}, 1462 \mathrm{~s}, 1386 \mathrm{~s}, 1362 \mathrm{~m}, 1329 \mathrm{~m}$ $1305 \mathrm{~m}, 1256 \mathrm{~m}, 1227 \mathrm{w}, 1208 \mathrm{w}, 1181 \mathrm{w}, 1163 \mathrm{w}, 1106 \mathrm{~m}, 1095 \mathrm{w}$, $1060 \mathrm{~m}, 978 \mathrm{w}, 935 \mathrm{~m}, 800 \mathrm{~s}, 768 \mathrm{~s}, 753 \mathrm{vs}, 683 \mathrm{w} \mathrm{cm} \mathrm{cm}^{-1}$

14 A. J. Arduengo III, R. Krafczyk, R. Schmutzler, H. A. Craig, J. R. Goerlich, W. J. Marshall and M. Unverzagt, Tetrahedron, 1999, 55, 14523-14534.

15 (a) W. Levason, G. Reid anbd W. Zhang, J. Fluorine Chem., 2015 172, 62-67; (b) M. Bortoluzzi, F. Marchetti, G. Pampaloni, M. Pucino and S. Zacchini, Dalton Trans., 2013, 42, 13054-13064; (c) S. L. Benjamin, A. Hyslop, W. Levason and G. Reid, J. Fluorine Chem. 2012, 137, 77-84; (d) M. Jura, W. Levason, R. Ratnani, G. Reid and M. Webster, Dalton Trans., 2010, 39, 883-891.

16 (a) W. Levason, M. E. Light, G. Reid and W. Zhang, Dalton Trans., 2014, 43, 9557-9566; (b) S. L. Benjamin, W. Levason and G. Reid, Chem. Soc. Rev., 2013, 42, 1460-1499; (c) F. Marchetti, G. Pampaloni, C. Pinzino and S. Zacchini, Eur. J. Inorg. Chem., 2013 5755-5761.

17 M. Bortoluzzi, M. Hayatifar, F. Marchetti, G. Pampaloni and S. Zacchini, Inorg. Chem., 2015, 54, 4047-4055.

18 F. Marchetti, G. Pampaloni and S. Zacchini, Eur. J. Inorg. Chem., 2008, 453-462.

19 (a) N. C. Tomson, J. Arnold and R. G. Bergman, Organometallics, 2010, 29, 2926-2942; (b) K. F. Hirsekorn, A. S. Veige, M. P. Marshak, Y. Koldobskaya, P. T. Wolczanski, T. R. Cundari and E. B. Lobkovsky, J. Am. Chem. Soc., 2005, 127, 4809-4830; (c) G. S. McGrady, A. Haaland, H. P. Verne, H. V. Volden, A. J. Downs, D. Shorokhov, G. Eickerling and W. Scherer, Chem. Eur. J., 2005, 11, 4921-4934; (d) M. Schormann, S. P. Varkey, H. W. Roesky and M. Noltemeyer, J. Organomet. Chem., 2001, 621, 310-316.

20 F. Marchetti, G. Pampaloni and S. Zacchini, RSC Adv., 2014, 4, 60878-60882.

21 (a) V. P. Tarasov, V. I. Privalov and Yu. A. Buslaev, Mol. Phys., 1978, 35, 1047-1055; (b) R. G. Kidd and H. G. Spinney, Inorg. Chem., 1973, 12, 1967-1971.

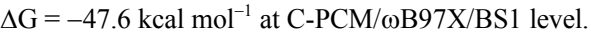

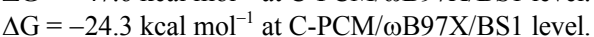

24 Calculated $\Delta \mathrm{G}$ values $\left(\mathrm{kcal} \mathrm{mol}{ }^{-1}\right)$ for the reaction $\mathrm{MX}_{5}+\mathrm{Ipr} \rightarrow$ $\mathrm{MX}_{5}$ (Ipr): $\mathrm{M}=\mathrm{Nb}, \mathrm{X}=\mathrm{Cl},-13.4(-16.1$ at $\mathrm{C}-\mathrm{PCM} / \omega \mathrm{B} 97 \mathrm{X} / \mathrm{BS} 1$ level); $\mathrm{M}=\mathrm{Nb}, \mathrm{X}=\mathrm{Br},-7.4 ; \mathrm{M}=\mathrm{Ta}, \mathrm{X}=\mathrm{Cl} ;-13.3 ; \mathrm{M}=\mathrm{Ta}, \mathrm{X}=$ $\mathrm{Br},-11.8$.

$\Delta \mathrm{G}=-7.2 \mathrm{kcal} \mathrm{mol}^{-1}$ at C-PCM/ $/ \mathrm{B} 97 \mathrm{X} / \mathrm{BS} 1$ level

A. Bondi, J. Phys. Chem., 1964, 68, 441.

E. V. Ilyakina, A. I. Poddel'sky, A. V. Piskunov, G. K. Fukin, A. S. Bogomyakov, V. K. Cherkasov and A. Abakumov, New J. Chem., 2012, 36, 1944.

28 F. Marchetti, G. Pampaloni and S. Zacchini, J. Fluorine Chem., 2010, 131, 21-28, and references therein.

29 F. Calderazzo, P. Pallavicini, G. Pampaloni and P. F. Zanazzi, J. Chem. Soc., Dalton Trans., 1990, 2743-2746.

30 L. Hintermann, Beilst. J. Org. Chem., 2007, 3, doi:10.1186/18605397-3-22.

31 W. Willker, D. Leibfritz, R. Kerssebaum and W. Bermel, Magn. Reson. Chem., 1993, 31, 287-292.

32 D. A. Skoog, D. M. West and F. J. Holler, Fundamentals of Analytical Chemistry, 7th Edition, Thomson Learning, Inc, USA, 1996.

33 G. M. Sheldrick, SADABS, Program for empirical absorption correction, University of Göttingen, Germany, 1996.

34 G. M. Sheldrick, SHELX97, Program for crystal structure determination, University of Göttingen, Germany, 1997.

35 (a) Yu. Minenkov, Å. Singstad, G. Occhipinti and V. R. Jensen, Dalton Trans., 2012, 41, 5526-5541; (b) J.-D. Chai and M. HeadGordon, Phys. Chem. Chem. Phys., 2008, 10, 6615-6620; (c) I. C. Gerber and J. G. Ángyán, Chem. Phys. Lett., 2005, 415, 100-105.

36 (a) M. M. Francl, W. J. Pietro, W. J. Hehre, J. S. Binkley, M. S. Gordon, D. J. DeFrees and J. A. Pople, J. Chem. Phys., 1982, 77, 3654-3665; (b) L. E. Roy, P. J. Hay and R. L. Martin, J. Chem. Theory Comput., 2008, 4, 1029-1031.

37 F. Weigend and R. Ahlrichs, Phys. Chem. Chem. Phys., 2005, 7 3297-3305.

38 (a) V. Barone and M. Cossi, J. Phys. Chem. A, 1998, 102, 1995-2001; (b) M. Cossi, N. Rega, G. Scalmani and V. Barone, J. Comput. Chem., 2003, 24, 669-681. 
C. Y. Lin, M. W. George and P. M. W. Gill, Aust. J. Chem,. 2004, 57, 365-370.

40 (a) W. J. Henre, R. Ditchfield and J. A. Pople, J. Chem. Phys., 1972 , 56, 2257-2261; (b) P. J. Hay and W. R. Wadt, J. Chem. Phys., 1985, 82, 270-283; (c) P. J. Hay and W. R. Wadt, J. Chem. Phys., 1985, 82, 299-310; (d) M. Dolg, Modern Methods and Algorithms of Quantum Chemistry, J. Grotendorst Ed., John Neumann Institute for Computing, NIC series, Jülich, 2000, 1, 479.
C. J. Cramer, Essentials of Computational Chemistry, 2nd Edition, Wiley, Chichester, 2004

42 Gaussian 09, Revision C.01, M. J. Frisch et al., Gaussian, Inc., Wallingford CT, 2010.

43 Spartan '08, version 1.1.1, Wavefunction, Inc., Irvine CA, 2009. Except for molecular mechanics and semi-empirical models, the calculation methods used in Spartan have been documented in: Y. Shao et al. Phys. Chem. Chem. Phys., 2006, 8, 3172-3191. 